Article

\title{
A Smart Strategy for Sizing of Hybrid Renewable Energy System to Supply Remote Loads in Saudi Arabia
}

\author{
Majed A. Alotaibi ${ }^{1,2}$ (D) and Ali M. Eltamaly ${ }^{1,3,4, *(\mathbb{D})}$ \\ 1 Saudi Electricity Company Chair in Power System Reliability and Security, King Saud University, \\ Riyadh 11421, Saudi Arabia; majedalotaibi@ksu.edu.sa \\ 2 Department of Electrical Engineering, College of Engineering, King Saud University, \\ Riyadh 11421, Saudi Arabia \\ 3 Sustainable Energy Technologies Center, King Saud University, Riyadh 11421, Saudi Arabia \\ 4 Electrical Engineering Department, Mansoura University, Mansoura 35516, Egypt \\ * Correspondence: eltamaly@ksu.edu.sa
}

check for updates

Citation: Alotaibi, M.A.; Eltamaly, A.M. A Smart Strategy for Sizing of Hybrid Renewable Energy System to Supply Remote Loads in Saudi Arabia. Energies 2021, 14, 7069. https://doi.org/10.3390/en14217069

Academic Editor: Byoung Kuk Lee

Received: 29 September 2021

Accepted: 22 October 2021

Published: 28 October 2021

Publisher's Note: MDPI stays neutral with regard to jurisdictional claims in published maps and institutional affiliations.

Copyright: (c) 2021 by the authors. Licensee MDPI, Basel, Switzerland. This article is an open access article distributed under the terms and conditions of the Creative Commons Attribution (CC BY) license (https:// creativecommons.org/licenses/by/ $4.0 /)$.

\begin{abstract}
The use of hybrid renewable energy systems (HRES) has become the best option for supplying electricity to sites remote from the central power system because of its sustainability, environmental friendliness, and its low cost of energy compared to many conventional sources such as diesel generators. Due to the intermittent nature of renewable energy resources, there is a need however for an energy storage system (ESS) to store the surplus energy and feed the energy deficit. Most renewable sources used battery storage systems (BSS), a green hydrogen storage system (GHSS), and a diesel generator as a backup for these sources. Batteries are very expensive and have a very short lifetime, and GHSS have a very expensive initial cost and many security issues. In this paper, a system consisting of wind turbines and a photovoltaic (PV) array with a pumped hydro energy storage (PHES) system as the main energy storage to replace the expensive and short lifetime batteries is proposed. The proposed system is built to feed a remote area called Dumah Aljandal in the north of Saudi Arabia. A smart grid is used via a novel demand response strategy (DRS) with a dynamic tariff to reduce the size of the components and it reduces the cost of energy compared to a flat tariff. The use of the PHES with smart DRS reduced the cost of energy by $34.2 \%$, and $41.1 \%$ compared to the use of BSS and GHSS as an ESS, respectively. Moreover, the use of $100 \%$ green energy sources will avoid the emission of an estimated 2.5 million tons of greenhouse gases every year. The proposed system will use a novel optimization algorithm called the gradually reduced particles of particle swarm optimization (GRP-PSO) algorithm to enhance the exploration and exploitation during the searching iterations. The GRP-PSO reduces the convergence time to $58 \%$ compared to the average convergence time of 10 optimization algorithms used for comparison. A sensitivity analysis study is introduced in this paper in which the effect of $\pm 20 \%$ change in wind speed and solar irradiance are selected and the system showed a low effect of these resources on the Levelized cost of energy of the HRES. These outstanding results proved the superiority of using a pumped-storage system with a dynamic tariff demand response strategy compared to the other energy storage systems with flat-rate tariffs.
\end{abstract}

Keywords: smart grid; hybrid; renewable; sizing; demand response; pumped hydro energy storage; particle swarm optimization

\section{Introduction}

Renewable energy sources like wind turbines and photovoltaic (PV) systems have become attractive options for supplying loads in remote areas due to their clean and economic characteristics. Their intermittent nature needs however an energy storage system (ESS) such as batteries or green hydrogen systems. The ESS is very important to save the surplus power when the generation from renewable resources is higher than the load and it supplies the load when the load demand is greater than the power generated 
by the renewable energy sources. Some systems use diesel generators or a conventional source of energy as a backup for the HRES when the storage system cannot feed the loads with the power needed. Some studies applied smart grid concepts using demand response strategies to reduce the size of the HRES components which can be translated into a substantial reduction in the cost of the energy obtained from the HRES [1]. The demand response uses dynamic tariff strategies to share the responsibility of the HRES stability with customers by shifting their loads based on the current tariff.

Many ESS systems used with hybrid renewable energy systems (HRES) represent a substantial part of the total cost. An enormous amount of work is introduced in the literature to reduce the cost of storage systems by using modern battery technologies that have a longer lifetime and better performance like lithium-ion batteries [2]. This however will not reduce the cost of energy substantially because of the increased cost of the lithium-ion batteries and the safety issues associated with this type of battery. Moreover, the excessive use of lithium-ion batteries in renewable energy and electric vehicles could cause a shortage in supply of the minerals used in this industry shortly and most of the minerals used in lithium-ion batteries are also located in only a few countries around the world, which could cause geopolitical conflicts shortly [3]. Some other studies recommend using green hydrogen storage systems (GHSS) composed of fuel cells, hydrogen tank(s), and electrolyzers as ESS [4]. However, this option is still not economically feasible due to the high cost of the components and the safety issues associated with this kind of system. These problems associated with battery storage systems (BSS) and GHSS have forced researchers and decision-makers to search for other technologies that can be used as an ESS for HRES. The use of pumped hydro energy storage (PHES) systems can solve this dilemma, especially in locations that have different topological levels that help reduce the cost of installing this type of ESS. A location with a high difference in elevation will reduce the installation cost of PHES systems and will contribute to a reduction of the sizes of the lakes needed due to the high difference in height between the upper and lower lakes. There is no fixed initial cost or running cost for a pumped hydro energy storage (PHES) system because it depends mainly on the site specifications such as the height difference, source of water, and the type of land. The relation between the length of the waterway (penstock) to the difference in height between the upper and lower reservoirs is called the $\mathrm{L} / \mathrm{H}$ ratio and sites with an $\mathrm{L} / \mathrm{H}$ ratio lower than 10 are very promising for pumped storage installations [5]. Any sites with an $\mathrm{L} / \mathrm{H}$ ratio greater than 10 are considered infeasible to use for a PHES [5]. Given the topography of the study site, a PHES system is selected in this paper to be used as a primary storage system and it will be compared with other energy storage systems like batteries and green hydrogen systems.

The PHES is recommended for use as energy storage, especially for large-size HRES and as energy support for existing power systems. This type of ESS has been used in many projects and studies around the world [6-11]. These PHES systems can work as off-grid [6-8] or on-grid systems [9-11] as well.

One more technology will reduce the size of the components of the HRES, especially the ESS, which is the demand response management (DRM) [1,12]. The use of DRM as one of the smart grid tools will allow the customers to participate in the stability of the HRES. This can be accomplished by using a dynamic tariff strategy to increase the tariff during periods of low electric generation availability from renewable resources to reduce the load and reduce the tariff when the generation from the renewable resources supply is higher than the load requirements. This strategy has been introduced using a new relationship between the state of charge $(\mathrm{SoC})$ of the battery, the power difference between the generation and load, and the tariff based on the power elasticity demand [1]. Another study introduced a fuzzy controller to adapt the tariff changes based on the situation of the HRES and the previous responses of customers [12]. In this study, the fuzzy logic control (FLC) method will be used as a controller to dynamically and actively adapt the tariff based on the previous response from the customers. In the proposed strategy introduced in this paper, a fuzzy logic controller is used to actively adapt the tariff based on the water levels 
of the upper lake of the PHES, the power difference between the generation and load, and the forecast factor $(F F)$ that considers the forecasted loads and weather conditions to predict the near future stability conditions of the HRES. This forecast factor uses the difference between the generated power from renewable energy resources and the forecasted loads for the coming several hours. The use of DRM through the use of the new proposed demand response strategy (DRS) introduced in this paper substantially reduces the size of HRES components without affecting the reliability of the system which can be translated into a substantial reduction in the cost of the generated energy.

Sizing the HRES is a very important stage before starting the installation stage to determine the feasibility and reliability of the system. Most sizing strategies used different objective functions to be minimized; some of these objective functions are economical, technical, or environmentally-based. Some studies design the HRES for minimum cost as a single objective function [13-19] and some other studies (multi-objective optimization ones) use more than one objective function to size and design the HRES [20-25]. The use of multi-objective optimization permits better operation of the HRES concerning different techno-economic factors. The design step can be performed based on an average analysis or it can be based on the timely version where the whole year is taken as an operating interval and the HRES should be able to feed the complete loads during all the hours of the year $[1,12]$. The latter strategy can give more accurate results than the average one, but it will a long time in the optimization stage and it may make the convergence time of the optimization very long. Many studies have been done to reduce the convergence time of the optimization by comparing different optimization algorithms and recommending a fast and reliable one [23,24]. Some other strategies change the number of search agents to reduce the convergence time, but this may make the optimization converge at a premature solution [26]. The failure rate is a factor that represents the ratio of how many runs of the optimization algorithm failed to converge at the optimal solution to the total number of runs of the algorithm. The cross-relation between the convergence time and failure rate to choose the number of search agents is a hard job where the increase of the number of search agents reduces the false (premature) convergence, but it will increase the convergence time. On the other way, the reduction of the number of search agents of the optimization algorithm reduces the convergence time but it will increase the probability of premature or failed convergence. Some studies make a trade-off between the convergence time and premature convergence to select the optimal number of search agents (swarm size) [27-30]. This optimal number of search agents will not solve the problem completely but it will give a midway solution for this dilemma. This dilemma is solved completely in this study by using a modified PSO optimization algorithm called gradually reduced particles of particle swarm optimization (GRP-PSO) algorithm in which it will start with a high number of search agents and these agents are reduced gradually during the optimization steps by removing the worst solution in each iteration. This new proposed strategy reduced the convergence time substantially with very accurate results.

The contributions out of this study can be summarized in the following points:

(1) The use of pumped storage systems in remote areas of Saudi Arabia is proposed, and it was compared with different types of ESS like batteries and green hydrogen storage systems.

(2) The use of a modern demand response strategy is introduced in which it allows customers to participate in the stability of the HRES. The novel demand response strategy uses the water level of the pumped storage system to suggest the electricity tariff taking the future data of load and weather into consideration.

(3) The use of DRM utilizing the new proposed demand response strategy (DRS) is introduced in this paper that substantially reduces the size of the needed HRES components which can be translated into a substantial reduction in the cost of energy.

(4) A novel forecast factor has been introduced to participate in ensuring the stability of the HRES. 
(5) The use of an improved PSO optimization algorithm with a reduced number of search agents reduces the convergence time while providing accurate results.

The above contributions were applied to the supply of a load in a remote site called Dumah AlJandal in the Al-Jouf province in the north of Saudi Arabia. Most of the loads around this site are used for agriculture and ranching industries which currently depend mainly on diesel generators. The use of strong HRES at this site will improve the living standard in these communities and reduce the pollution emission from diesel generators and substantially reduce the cost of energy. In addition to all these benefits in that area, the ideal use of the PHES in this location adds another incentive to start this new HRES project.

To show the new proposed sizing strategy of the HRES using a novel DRS, the following sections have been introduced. Section 2 shows the configuration of the HRES. The modeling of the HRES components are introduced in Section 3. The new DRS is introduced in Section 4. Section 5 introduces the power dispatch strategy. The proposed GRP-PSO Algorithm is introduced in Section 6, where the economic analysis details are introduced in Section 7. Finally, the simulation results are shown in Section 8, and the conclusions are introduced in Section 9.

\section{System Configuration}

\subsection{Site Specifications}

The selected site to build the HRES is near the Dumah AlJandal site in the north of Saudi Arabia, shown in Figure 1 [31]. The idea behind choosing this site is due to its location far from the center of the Saudi electricity grid and the need for electricity for the remote communities around this location, moreover, it is a suitable location to build a PHES system as there is an existing lake at $600 \mathrm{~m}$ height called Dumah AlJandal lake. The size of the Dumah Aljandal lake is about 1 million square meters and it is $585 \mathrm{~m}$ deep giving it a storage capacity of about 11 million cubic meters [32]. The proposed upper lake will be on the nearby mountain with an elevation $700 \mathrm{~m}$ above sea level which means that there is a $100 \mathrm{~m}$ difference between the two lakes. The upper lake needs a dam in front of the lake. The cost of the dam depends on the proposed depth of the upper lake and the lake size also depends on the height of the dam. The proposed penstock length is about $1 \mathrm{~km}$. The upper lake size will be determined from the simulation for the lowest cost of energy and highest reliability.

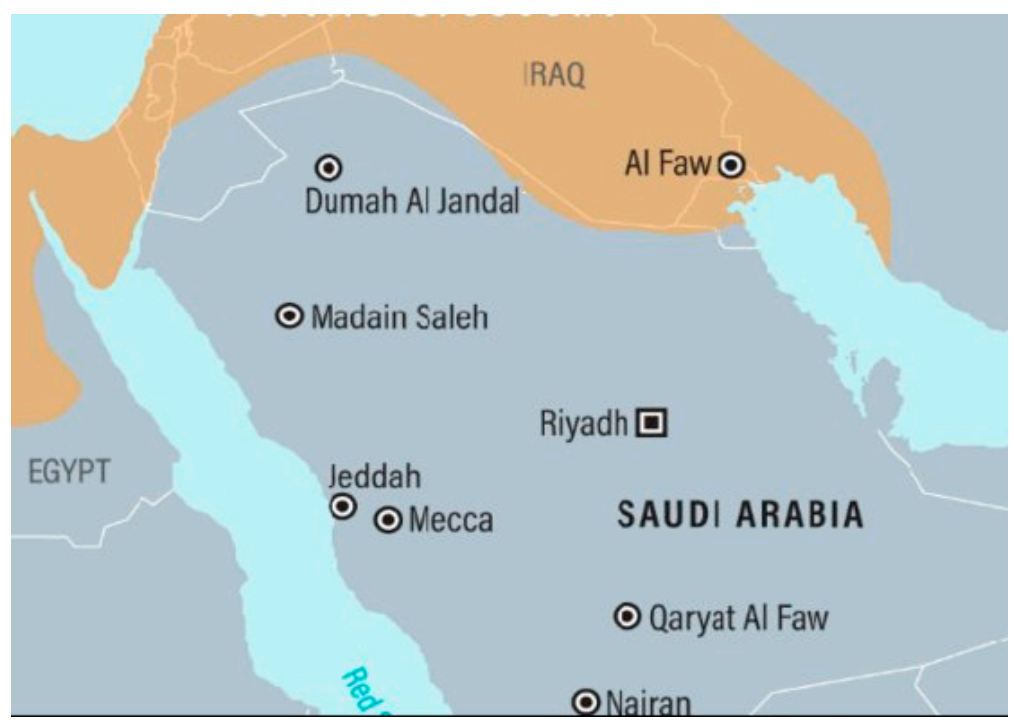

Figure 1. The location of the Dumah AlJandal site within a map of Saudi Arabia [31]. Reproduced from [31], Horizon Research Publishing: 2021. 
Two pictures are shown in Figure 2 to show the locations of the PHES system. Figure 2a shows a topographical view with different colors depending on the elevation of the site. Figure $2 b$ shows a satellite view (from Google Earth) to show the characteristics of the proposed site. The area around this project will benefit from the proposed HRES as many areas around the project will have enough water and energy for desert reclamation to improve the ranching industry around the site. Moreover, most of the current loads rely on diesel generators, and replacing all these fossil fuel resources with a $100 \%$ green energy system will avoid a substantial part of the current greenhouse gas (GHG) emissions, which will improve the environment around this area and improve the health of residents and the livestock around this agricultural community.

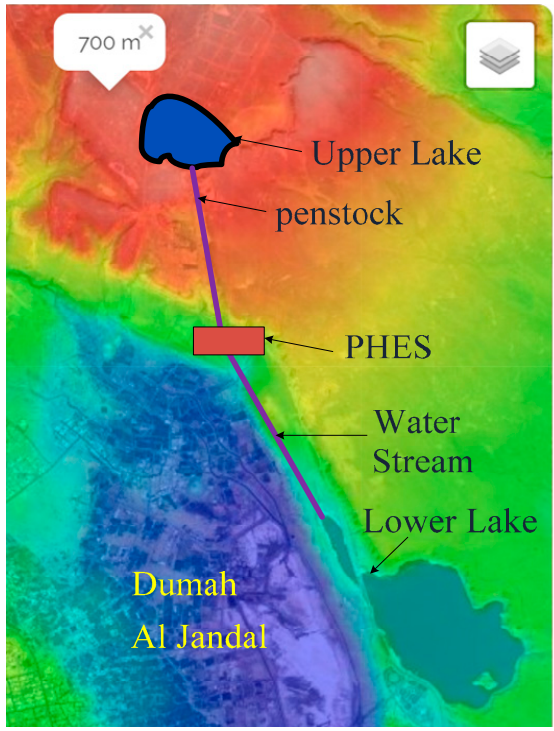

(a)

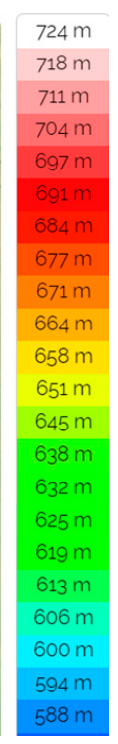

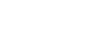

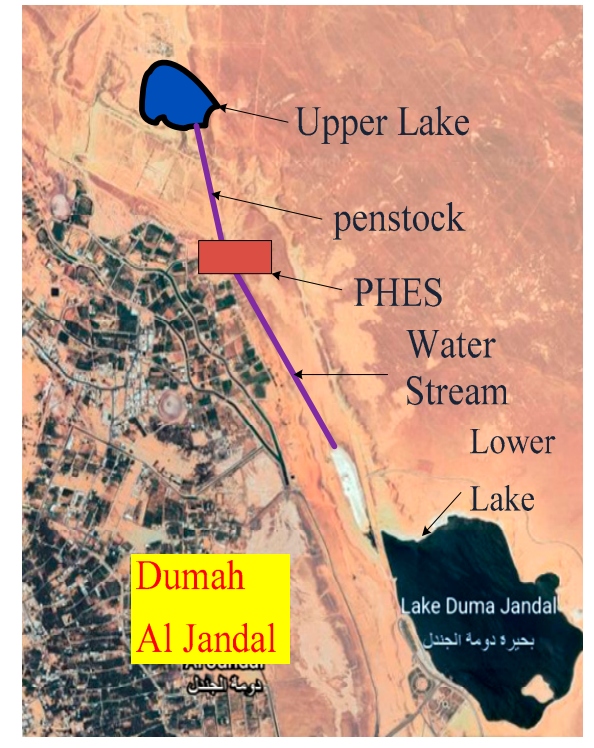

(b)

Figure 2. The proposed HRES in Dumah AlJandal site. (a): Topological view [33]. Reproduced from [33], Topographic maps: 2021. (b): GOOGLE EARTH view.

\subsection{HRES Configuration}

The HRES will work with the microgrid in the area to support the loads in the Dumah Aljandal site. The proposed HRES is used to supply local loads of some villages around the system from renewable energy sources (PV and wind turbines) [1]. The proposed HRES system will work with 100\% green energy with the help of the PHES system, the other storage systems (green hydrogen and lithium-ion batteries) will be used for comparison. The configuration of the proposed HRES is shown in Figure 3. In this configuration, the PHES system will work to store the energy as potential energy when the generation is higher than the loads need and discharge the water from the upper lake to the lower lake when the load power is greater than the renewable energy sources power as described in Figure 4. The other storage systems, GHSS and BSS will work in the same concept to be compared with the PHES. The proposed system including PHES, GHSS, and BSS will use the time of use tariff as one of the smart grid concepts in the operation and sizing of the components of the HRES. This DRS is implemented in a fuzzy logic controller (FLC) as will be discussed in the following sections. 


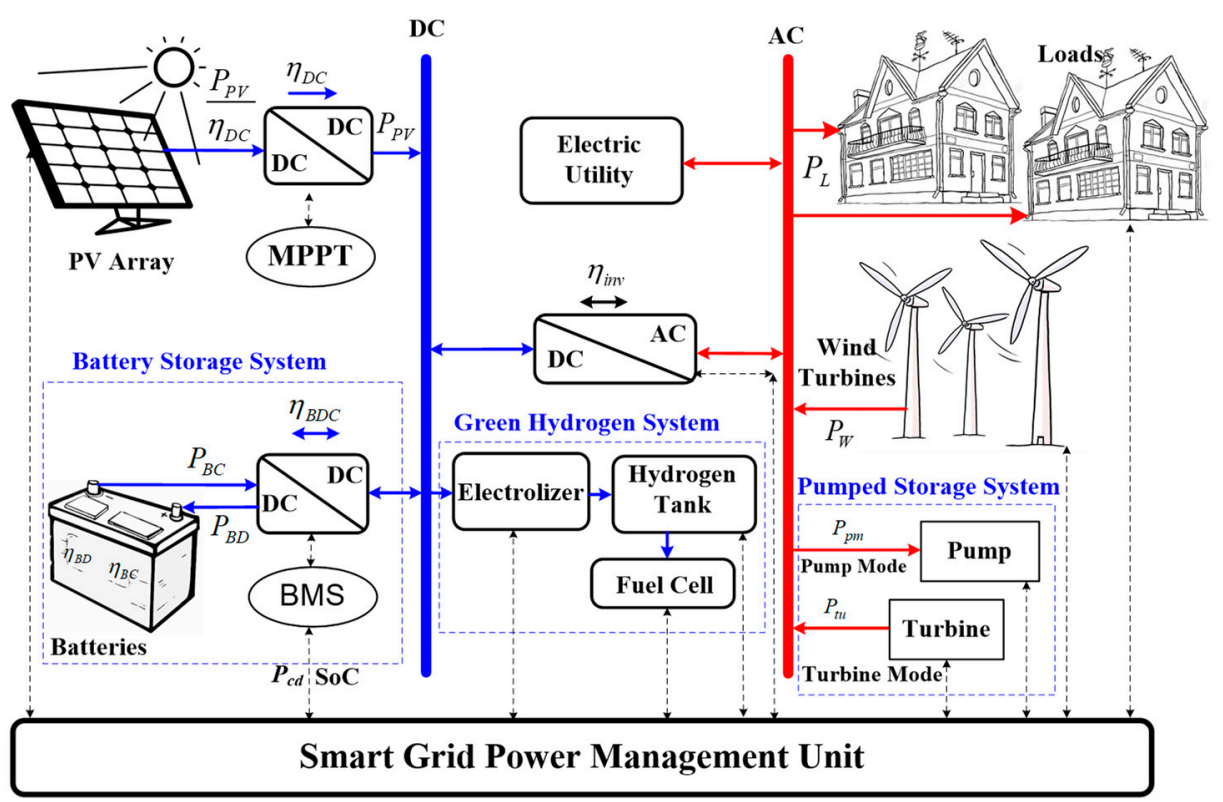

Figure 3. The connection of the proposed HRES.

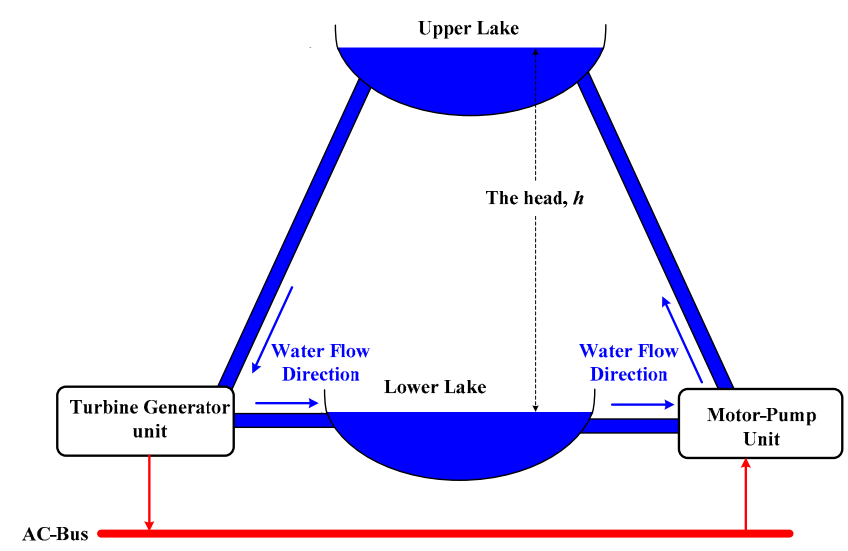

Figure 4. The water and electric power flow through the pumped storage system.

\section{System Modeling}

The proposed HRES is having a PV array, wind turbines, and one ESS. Three different storage systems will be studied to be used separately with the proposed HRES for comparison, PHES, GHSS, and BSS systems. The modeling of each component of the HRES is shown in the following subsections.

\subsection{Wind Energy System Modelling}

Wind speeds at the proposed site are collected at the elevation of $40 \mathrm{~m}$ above the ground level ( $590 \mathrm{~m}$ above sea level). The wind turbines will be installed at the top of the mountain (700 $\mathrm{m}$ above sea level). The wind speed should be modified to the elevation of the wind turbine at the hub height of the wind turbine which is 100 plus the hub height of the wind turbine $\left(100+h_{w t}\right)$. The relation between the wind speed at the elevation of the wind turbine to the elevation of the measurements of wind speed (anemometer elevation) is shown in Equation (1) [34] (wind speed data are collected at $40 \mathrm{~m}$ above sea level for Dumah AlJandal site as will be shown in details in the simulation analysis section):

$$
\frac{u\left(h_{w t}\right)}{u\left(h_{a}\right)}=\left(\frac{h_{w t}}{h_{a}}\right)^{\alpha}
$$


where, $h_{w t}$ is the hub height of the wind turbine above the sea level, $h_{a}$ is the height of the anemometer above the sea level, is an exponent that may differ from site to site and it has an average value equal 1/7 [34].

The generated power from the wind turbine is a function of the wind speed. The relation between the generated power from the wind turbines and the wind speed is shown in Equation (2) [35]:

$$
P_{W}(u)=\left\{\begin{array}{lr}
0 & u \leq U_{C} \& u \geq U_{F} \\
P_{R} \cdot \frac{u^{K}-U_{C}^{K}}{U_{R}^{K}-U_{C}^{K},} & U_{C} \leq u \leq U_{R} \\
P_{R} & U_{R} \leq u \leq U_{F}
\end{array}\right\}
$$

where, $U_{C}, U_{R}$, and $U_{F}$ are the cut-in, rated and cut-off wind speeds of the wind turbine, $K$ is the shape Weibull parameter of the site and wind turbine [36], $P_{R}$ is the rated power of the WT.

\subsection{Photovoltaic Energy System Modelling}

The PV system is connected to the DC-bus of the HRES using a DC-DC converter. The purpose of the DC-DC converter is to control the PV terminal voltage to force the PV array to work at the maximum available power where there is a nonlinear relation between the power and voltage of the PV array. This nonlinear relation between the power and voltage of the PV array is called the P-V characteristics. This nonlinear relation contains only one peak in the case of uniform irradiance, but it has multiple peaks in the case of partial shading. Due to this dynamic nonlinear relation, a maximum power point tracker (MPPT) should be used to actively track the maximum power available from the PV array [37-39].

Solar irradiances on a horizontal surface and the temperatures for the Dumah AlJandal site have been collected, as will be shown in detail in the simulation analysis section. The generated power from the PV array also is a function in the area of the solar array, the generation efficiency of the PV modules, solar irradiance, and the ambient temperature around the cells. The relation showing the PV-generated power can be determined from Equation (3), where $H_{t}(t)$ is the solar irradiance on the PV array, PVA, $\eta_{c}(t)$ is the convergence efficiency of the PV module which can be determined from Equation (4), where $\eta_{D C}$ is the efficiency of the DC-DC converter, $T_{c r}$ is the rated temperature of PV modules, $T_{c}(t)$ is the current temperature of PV cells, which can be determined from Equation (5), where $\beta_{t}$ is the temperature coefficient on cell efficiency which has a value of about 0.005 per ${ }^{\circ} \mathrm{C}[40]$ :

$$
\begin{gathered}
P_{P V}(t)=H_{t}(t) \cdot P V A \cdot \eta_{c}(t) \cdot \eta_{D C} \\
\eta_{c}(t)=\eta_{c r}\left[1-\beta_{t} \cdot\left(T_{c}(t)-T_{c r}\right)\right] \\
T_{c}(t)=T_{a}(t)+3 H_{t}(t)
\end{gathered}
$$

\subsection{Pumped Hydro-Energy Storage System Modelling}

The proposed pumped storage shown in Figure 4 has an induction motor attached to the water pump to suck the water from the lower lake to the upper lake when the generated power from the renewable resources is greater than the loads need. The relation between the power needed to suck the flowrate of water certain amount of water can be obtained from Equation (6) [41]:

$$
Q_{p m}(t)=P_{p m}(t) \cdot \eta_{p m} \cdot 3600 /\left(\rho_{w} \cdot g \cdot h\right)
$$

where $P_{p m}(t)$ is the electric power consumed by the pump $Q_{p m}(t)$ of water in $\mathrm{m}^{3} / \mathrm{h}, h$ is the water head in $\mathrm{m}, \eta_{p m}$ is the pump efficiency, $\rho_{w}$ is the water density, $g$ is the gravitational acceleration constant [41]. 
The relation between the water discharged flow rate in $\mathrm{m}^{3} / \mathrm{h}$ from the upper lake to the lower one can be obtained from Equation (7) [41]:

$$
Q_{t u}(t)=P_{t u}(t) \cdot 3600 /\left(\eta_{t u} \cdot \rho_{w} \cdot g \cdot h\right)
$$

where, $P_{t u}(t)$ is the generated power from the turbine when the flow rate through a turbine is $Q_{t u}(t) \mathrm{m}^{3} / \mathrm{h}, \eta_{t u}$ is the water turbine efficiency.

\subsection{Green Hydrogen Modelling}

As shown in Figure 3, the green hydrogen storage system consists of an electrolyzer, hydrogen tank, and fuel cell units. The electrolyzer will consume the surplus power generated from the renewable energy resources to break the bonds between the hydrogens and oxygen in the water and collect hydrogen in the hydrogen tanks to be used when there is a shortage in the generated power from renewable sources than the load needs. The hydrogen stored in the hydrogen tank can be used to generate DC power through the fuel cell unit. The model of the proposed GHSS is modeled as shown in [42-46].

In the case where the generated power from renewable energy sources is greater than the load power, the surplus power $P_{E Z}(t)$ will be transferred to an electrolyzer to generate the amount of hydrogen $Q_{E Z}(t)$ as shown in Equation (8) [42,43]:

$$
P_{E Z}(t)=B_{E Z} \cdot Q_{N E Z}+A_{E Z} \cdot Q_{E Z}(t)
$$

where, $Q_{N E Z}$ is rated hydrogen flow $(\mathrm{kg} / \mathrm{h}), A_{E Z}$, and $B_{E Z}$ are the hydrogen consumption coefficients and have values $40 \mathrm{~kW} / \mathrm{kg} / \mathrm{h}$ and $20 \mathrm{~kW} / \mathrm{kg} / \mathrm{h}$, respectively [42]. This amount of hydrogen will be stored under pressure in the hydrogen tank where the efficiency of the high heating value of hydrogen can be obtained as shown in Equation (9) [44]:

$$
\eta_{E Z}(t)=\frac{39.4 \cdot Q_{E Z}(t)}{P_{E Z}(t)}
$$

The amount of hydrogen $(\mathrm{kg} / \mathrm{h})$ used to generate the amount of power, $P_{F C}$ from fuel cells can be obtained from Equation (10) [42]:

$$
Q_{F C}(t)=B_{F C} \cdot P_{N F C}+A_{F C} \cdot P_{F C}
$$

where $P_{N F C}$ is the rated power of the fuel cell, $A_{F C}=0.05$ and $B_{F C}=0.004$ are the consumption coefficients of the fuel cell [42].

The variation of fuel cell efficiency with the generated power can be obtained from Equation (11) [42,47]:

$$
\eta_{F C}=\frac{100 \cdot P_{F C}}{33.3 \cdot Q_{F C}(t)}
$$

In case the surplus power going to the electrolyzer is greater than the maximum allowable power of the electrolyzer, it will consume its rated power and the extra power will be transferred to the electric utility. The same logic is valid for the fuel cell, so when the deficit power is higher than the rated power of the fuel cell, it will work with its rated power and the rest of the power can be obtained from the utility grid.

\subsection{Battery Modelling}

The batteries will be charged when the generated power from the renewable resources is higher than the load and discharge its energy in the other operating condition. The state of charge $(S o C)$ of the batteries should be limited by two values, the minimum and maximum state of charge as shown in Equation (12):

$$
S o C^{\min }<\operatorname{SoC}(t)<S o C^{\max }
$$


where, $S o C^{\min }=\frac{E_{B}^{\min }}{E_{B}^{R}}, S o C^{\max }=\frac{E_{B}^{\max }}{E_{B}^{R}}, S o C(t)=\frac{E_{B}(t)}{E_{B}^{R}}, E_{B}^{\min }$, and $E_{B}^{\max }$ are the minimum and maximum allowable stored energy in the batteries, respectively. The rated energy of the batteries, $E_{B}^{R}$, which for sure is higher than the $E_{B}^{\max }$ to ensure safe operation of batteries with $S o C$ less than $100 \%$.

The difference between the maximum and minimum $S o C$ is a very important factor called the depth of discharge $(D o D)$ as shown in Equation (13). The $D o D$ is a very important factor in the design of the battery system in the HRES. The higher the value of $D o D$, the shorter the lifetime of the battery and vice versa. So, it is recommended to reduce the $D o D$ to prolong the lifetime of the batteries, meanwhile, the lower $D o D$ will increase the size of the battery system and will increase the cost of energy. For this reason, it is very important to compromise the value of $D o D$ to get the longest lifetime and the lower size of the battery system which can be performed by optimally determining the $D o D$ for minimum operating cost. The energy used from the battery system, $E_{B U}$ in terms of $D o D$ is shown in Equation (14). The relation between the aging cost of the batteries and the DoD is shown in Equation (15) [48]:

$$
\begin{gathered}
D o D=S o C^{\max }-S o C^{\min } \\
E_{B U}=D o D \cdot E_{B}^{R} \\
\text { Aging Cost }=\frac{C_{B}}{D o D}(1-S o H)
\end{gathered}
$$

where, $C_{B}$ is the total cost of the batteries. Lithium-ion batteries work until their $\mathrm{SoH}$ becomes equal to $80 \%$ and it is an indication for the end of their life [48]

The hourly battery power, $P_{B}(t)$ is the difference between the charging and discharging power and can be obtained as shown in Equation (16). The sign of $P_{B}(t)$ is positive when the generation from HES is greater than the load requirement (the battery is charging) and vice versa:

$$
P_{B}(t)=P_{B C}(t)-P_{B D}(t)
$$

where, $P_{B C}(t)$ and $P_{B D}(t)$ are the charging and discharging power from the battery at the DC-bus.

The batteries lose energy every hour when they are charging, discharging, or in the case of storing conditions, which is called self-discharging. The formula to determine the SoC of the batteries is shown in Equation (17) [49]:

$$
\operatorname{SoC}(t+1)=\operatorname{SoC}(t)\left(1-\frac{\sigma}{24}\right)+\frac{P_{B C}(t)}{E_{B}^{R} \cdot \eta_{B C}}-\frac{P_{B D}(t)}{E_{B}^{R} \cdot \eta_{B D}}
$$

where, $\sigma$ is the self-discharge rate which depends on the type, state of health $(\mathrm{SoH})$, operating temperature, and $\mathrm{SoC}$ of the battery. This value is used in many studies as $0.2 \%$ per day [50,51], $\eta_{B C}$ and $\eta_{B D}$ are the charging and discharging efficiencies of the batteries, respectively.

\section{The Proposed Demand Response Strategy}

The concepts of the smart grid are applied to the proposed system by using a dynamic tariff that can share the responsibility of the HRES stability with the customers. The proposed demand response strategy introduced in this paper uses the resources available of the HRES to suggest a tariff. The factors that can affect the stability of the HRES are the volume of water in the upper lake (the lower lake is assumed to have enough water all the time), the power difference between the generation from the renewable resources and the load power, and the forecast factor that can measure the future situation of the HRES taking into consideration the future power available from the renewable energy sources based on the weather conditions and the future load power which can be obtained from Equation (18). All these factors should be fed to the fuzzy logic controller (FLC) [52] to determine the new tariff to preserve the stability of the HRES. The proposed DR strategy 
using the FLC is shown in Figure 5. The structure of the FLC used with the DR strategy is shown in Figure 6. The sample of membership functions that can represent the logic used in the design of the DR strategy is shown in Figure 7.

$$
F F=\sum_{i=1}^{N_{F}} \frac{P_{G}(t+i)-P_{L}(t+i)}{P_{L A} \cdot(i+1)}
$$

$N_{F}$ is the total forecasted hours ( $N_{F}=10$ has been selected in this study); $P_{L A}$ is the average load power during the year which can be obtained from Equation (19):

$$
P_{L A}=\frac{1}{8760} \sum_{t=1}^{8760} P_{L O}(t)
$$

where, $P_{L O}$ is the original load power before applying the DR strategy which can be obtained from Equation (20):

$$
P_{L A}=\frac{1}{8760} \sum_{t=1}^{8760} P_{L O}(t)
$$

The operating limits of the upper lake are shown in Equation (21):

$$
V_{U}^{\min } \leq V_{U}(t) \leq V_{U}^{\max }
$$

where $V_{U}(t)$ is the volume of the upper lake $V_{U}^{\min }$ and $V_{U}^{\max }$ is the minimum and maximum allowable volume of the upper lake. The value representing the ratio between the current amount of water in the upper lake to the maximum limit is shown in Equation (22):

$$
R V_{U}(t)=V_{U}(t) / V_{U}^{\max }
$$

The price elasticity demand, PED is measuring the response of the customers to change their load based on the change in tariff which can be obtained from Equation (23).

The new tariff after adding the tariff increment is shown in Equation (24):

$$
\begin{gathered}
P E D=\frac{\Delta P_{L}(t) / P_{L A}}{\Delta \rho(t) / \rho_{0}} \\
\rho(t+1)=\rho(t)+\Delta \rho(t)
\end{gathered}
$$

where, $\rho(t)$ and $\rho(t+1)$ are the tariff at the current and next hour, respectively, $\Delta \rho$ is the change in tariff, $\rho_{0}$ is the basic tariff, $\Delta P_{L}$ is the change in load power.

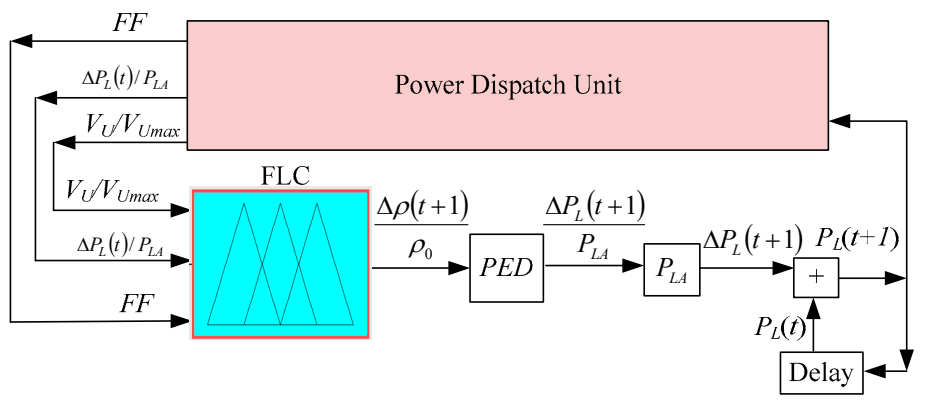

Figure 5. The block diagram of the demand response strategy with FLC. 


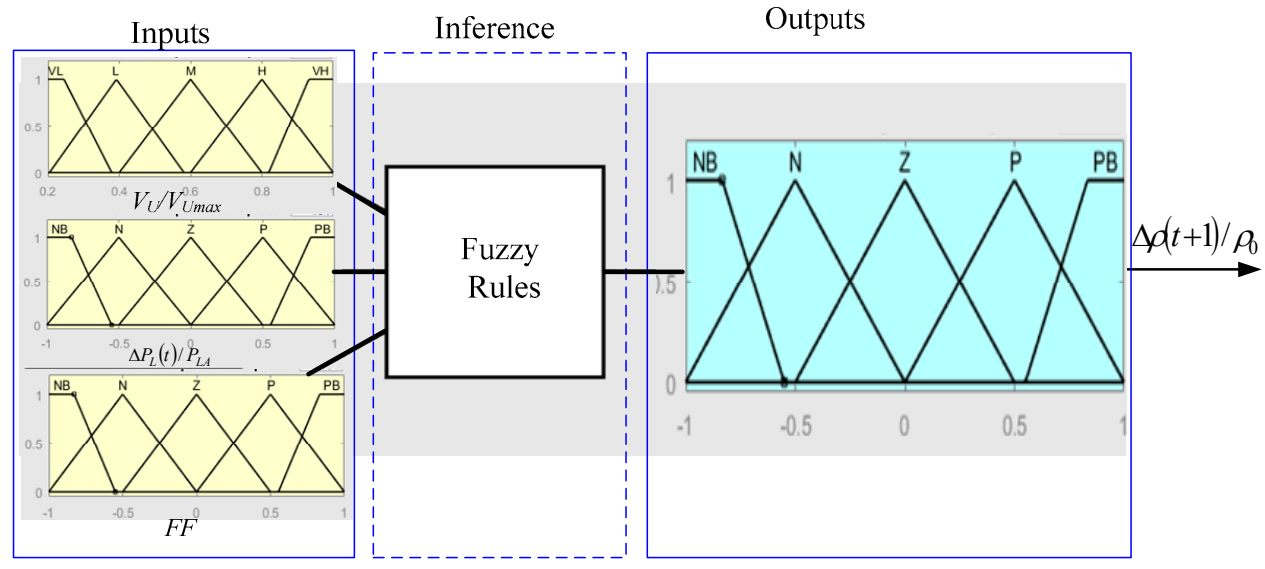

Figure 6. The structure of FLC.

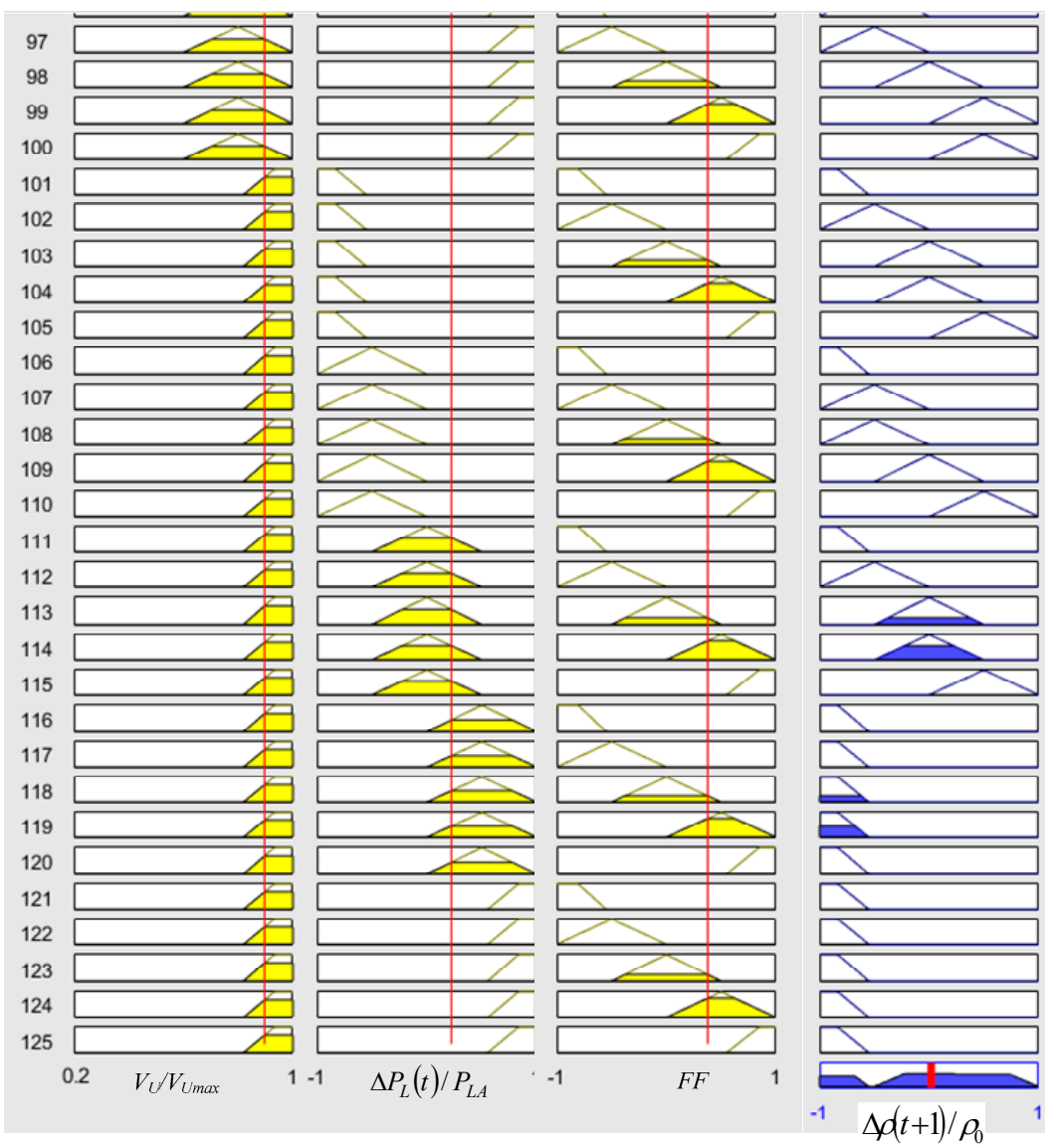

Figure 7. The sample of membership function that can represent the logic used in the design of the DRS.

\section{Power Dispatch Strategy}

The flow of power in the HRES is based on the value of generated power, the load power, and the situation of the upper lake. The power flow will ensure the system stability which can be shown in Figure 8 and explained in the following sections: 


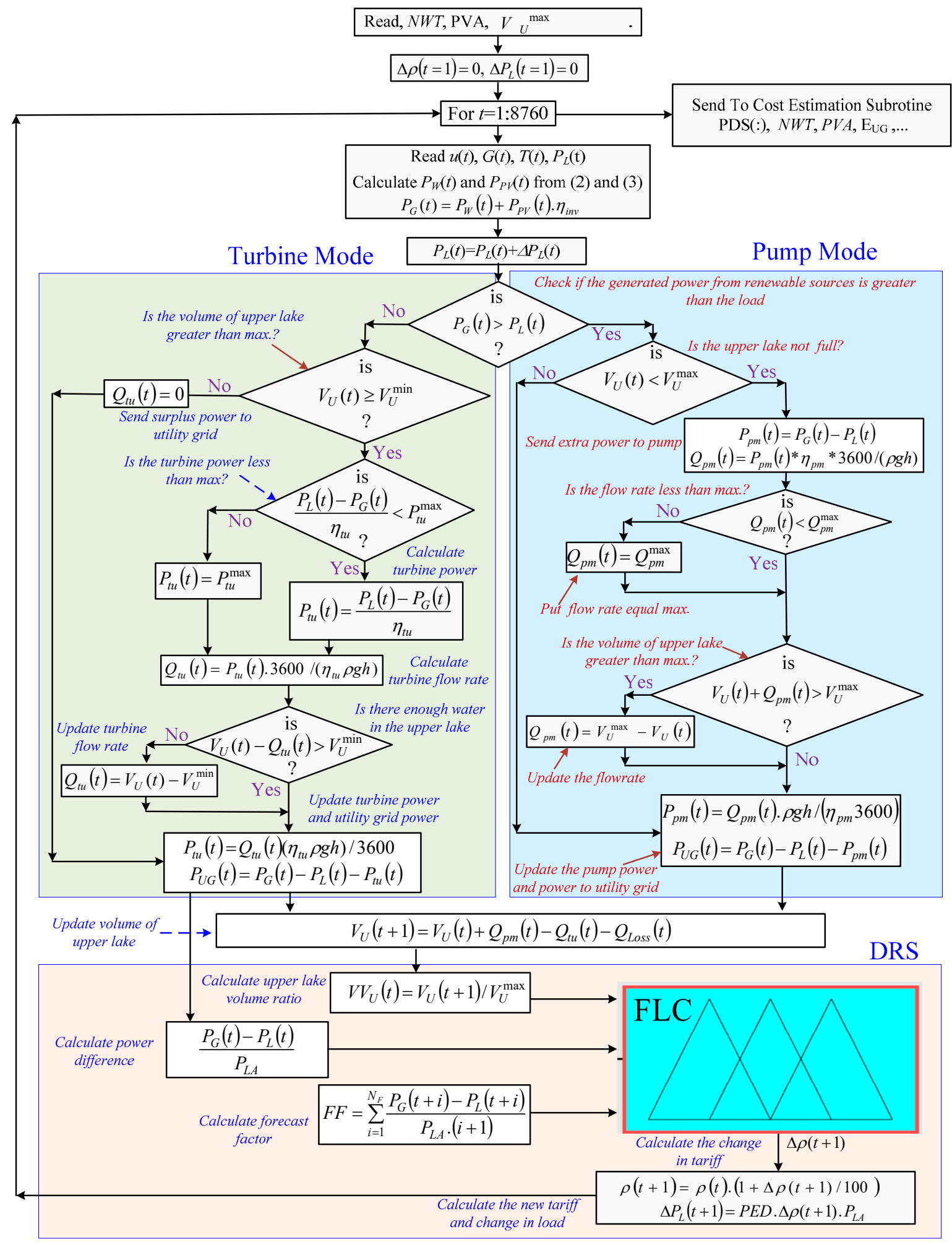

Figure 8. The dispatch strategy of using PHES as an ESS of the HRES.

\subsection{Pump Mode}

If the generated power from renewable energy is greater than the load power and the upper lake is not full $\left(P_{G}>P_{L}\right)$. The pump power can be determined from Equation (25) 
and the amount of power added to the upper lake can be determined from Equation (6). The new volume of the upper lake can be obtained from Equation (26):

$$
\begin{gathered}
P_{p m}(t)=P_{G}(t)-P_{L}(t) \\
V_{U}(t+1)=V_{U}(t)+Q_{p m}(t)
\end{gathered}
$$

In case of the $P_{G}>P_{L}$ and the upper lake is full, the surplus power will be fed to the dummy loads, then $P_{p m}(t)=0$ and $Q_{p m}(t)=0$.

\subsection{Turbine Mode}

In the case of the generated power from renewable energy is lower than the power required by the load $\left(P_{G}<P_{L}\right)$, and there is enough water in the upper lake to feed the power deficit, the generated energy from the turbine can be obtained from Equation (27) and the amount of water discharged from the upper lake can be obtained from Equation (7). The volume of water in the upper lake can be determined from Equation (28):

$$
\begin{gathered}
P_{t u}(t)=\left(P_{L}(t)-P_{G}(t)\right) / \eta_{t u} \\
V_{U}(t+1)=V_{U}(t)-Q_{t u}(t)-Q_{\text {Loss }}(t)
\end{gathered}
$$

If the volume of water in the upper lake is lower than the amount required to feed the load, then $P_{t u}(t)=0$ and $Q_{t u}(t)=0$, and in this case, the power deficit will be met with power fed from the electric grid.

\section{The Novel GRP-PSO Algorithm}

Optimization algorism is used to determine the optimal size of different components of the HRES. The optimization algorithm sends search agents to the power dispatch part and the cost estimation part to determine the corresponding value of the multi-objective function. The multi-objective function is used to determine the minimum cost plus the minimum energy transferred from the utility grid is shown in Equation (29).

The value of $\mathrm{M}$ is used to give the utility grid energy the weight compared to the $L C E$. The optimization algorithm uses the values of a multi-objective function, $F$ to determine its minimum value.

$$
F=L C E+M \cdot E_{U G} / E_{y}
$$

where, $L C E$ is the Levelized cost of energy, $E_{U G}$ is the yield energy transmitted or absorbed from the utility grid, and $E y$ is the yearly energy of the load.

The value of $\mathrm{M}$ is used to give the utility grid energy the weight compared to the LCE. The optimization algorithm uses the values of a multi-objective function, $F$ to determine its minimum value. The variables used in the objective function to be optimized are shown in the following points:

- $\quad$ Number of wind turbines, NWT

- $\quad$ Photovoltaic array area, $P V A$

- $\quad$ Size of the upper lake and the number of the pump-turbine set (Case-1).

- $\quad$ Size of batteries (Case-2)

- Size of the electrolyzer, hydrogen storage volume, and fuel cell size (Case-3)

The convergence time and failure rate are two important factors to evaluate the performance of the optimization algorithm. These two factors are cross-related concerning the number of particles (swarm size), where the low number of particles can give low convergence time but increase the cause higher failure rate and vice versa. The challenge introduced in this study is how to reduce the convergence time without increasing the failure rate. This challenge is solved by using a gradual reduction of the PSO particles with iterations using the GRP-PSO algorithm to enhance the exploration at the beginning of optimization and enhance the exploitation at the end. In this new proposed study, the GRP-PSO is chosen to start with a higher number of particles and it is reduced by one in 
each iteration. The results obtained from this study showed a substantial reduction in the conversion time and the failure rate. The PSO algorithm is started with random values of variables (particles' positions) for each particle and the value of the multi-objective function is determined as shown in Equation (29) (Particles' values). The change of position of each particle (particles' velocities) can be determined from (30). The new position of particles can be determined from Equation (31):

$$
\begin{gathered}
v_{i+1}{ }^{k}=\omega_{i} v_{i}{ }^{k}+c_{1} r_{1}\left(P_{b e s t, i}^{k}-d_{i}^{k}\right)+c_{2} r_{2}\left(G_{b e s t, i}-d_{i}^{k}\right) \\
d_{i+1}{ }^{k}=d_{i}{ }^{k}+v_{i+1}^{k}
\end{gathered}
$$

where, $\omega$ is the inertia weight, $c_{1}$ and $c_{2}$ are the acceleration coefficients, $P_{b e s t, i}$ is the personal best solution or best private solution of particle $i, G_{b e s t, i}$ is the global best of $P_{b e s t, i}, k$ is the swarm number, and $r_{1}$ and $r_{2}$ are random values in between $[0,1]$.

The inertia weight is used to establish a balance between exploration and exploitation. Many studies have recommended different fixed values for it [53-59], and some other studies have recommended a linearly decreasing value [60,61]. Most of these studies recommended starting the inertia weight value with 0.9 and ending with 0.4 [61] as shown in Equation (32):

$$
\omega_{i}=0.9-0.5 \cdot \frac{i}{I t_{\max }}, \text { where } i<=I t_{\max }
$$

where, $i$ is the number of the current iteration, and $I t_{\max }$ is the maximum number of iterations. This strategy enhances the fast convergence at the start of optimization and enhances the exploitation at the end of the optimization steps. The same inertia weight $(0.9 \rightarrow 0.4)$ as the one introduced in [61] will be used with the GRP-PSO for the same purpose. The GRP-PSO algorithm is compared with fixed inertia weight and fixed number of particles during optimization to evaluate the performance of the modified PSO in terms of the convergence time and failure rate. Moreover, the newly proposed technique is compared with 10 other optimization algorithms for the same purpose.

\section{Economic Analysis}

The economic study is the main part of the sizing of HRES. Many studies were introduced in the literature to perform this analysis [62-65]. The most important economic factor is the levelized cost of energy (LCE) $[1,62,63]$. Other economic factors have been introduced in the literature to evaluate the economic benefits of using the HRES such as net present value (NPV) [1,62], life cycle cost (LCC) [62] or annualized cost of system (ACS) [64]. A novel economic factor has been introduced by Belmilia et al. called the annualized lifecycle cost (ALCC) which represents the annualized cost of the system $[65,66]$. All these economical parameters can evaluate the feasibility of the HRES before the start of the installation stage.

The LCE is the main economic technique used in this paper to determine the cost of energy generated from the HRES as shown in Equation $(33)[1,63]$. The CRF is a capital recovery factor that depends on the project lifetime, and the interest rate, $\mathrm{r}$ as shown in Equation (34). The total present cost (TPC) is the total cost of the HRES at present (TPC). This value can be determined by adding the total initial cost plus the present value of the replacement cost $(R C)$, plus the present value of the operation and maintenance cost $(O M C)$, minus the present value of the salvage of the HRES (PSV) which can be obtained from Equation (35) [1,63]. The detailed methodology used in the calculations of the LEC is shown in [1].

$$
\begin{gathered}
L C E=\frac{T P C \cdot C R F}{E_{T}} \\
C R F=\frac{r(1+r)^{\tau}}{(1+r)^{\tau}-1} \\
T P C=C C+R C+O M C-P S V
\end{gathered}
$$




\section{Simulation Analysis}

The simulation analysis has been performed using the weather data of the Dumah AlJandal site where the hourly solar irradiance, temperature, and hourly wind speed were collected and their monthly average values are shown in Table 1, Figures 9 and 10. The monthly average load of this site has been collected from the actual load values of some villages near this site and, where the maximum load varies between 4.5 to $30 \mathrm{MW}$ [1]. The analysis of the proposed HRES is done using Matlab software (Version 9.9, release R2020b /MathWorks, Natick, MA, USA). The sampling time is performed on a one-hour basis with $8760 \mathrm{~h}$ per day.

Table 1. Wind speed collected at $40 \mathrm{~m}$ above sea level, Solar irradiance on a horizontal surface, temperature, and loads for Dumah AlJandal site [1,67].

\begin{tabular}{|c|c|c|c|c|c|c|c|c|c|c|c|c|c|}
\hline Month & Jan & Feb & Mar & Apr & May & Jun & Jul & Aug & Sep & Oct & Nov & Dec & Mean \\
\hline Wind speed & 5.6 & 5.5 & 6.5 & 6.1 & 5.9 & 6.3 & 6.6 & 5.7 & 5.5 & 5.5 & 5.4 & 5.5 & 5.84 \\
\hline $\begin{array}{l}\text { Solar Irradiance } \\
\mathrm{Wh} / \mathrm{m}^{2} / \mathrm{h}\end{array}$ & 162 & 202 & 254 & 296 & 319 & 347 & 346 & 317 & 281 & 222 & 173 & 151 & 256 \\
\hline $\mathrm{Ta}\left({ }^{\circ} \mathrm{C}\right)$ & 9.3 & 13.5 & 17.4 & 23.3 & 28.2 & 33.0 & 34.8 & 36 & 30.4 & 25.3 & 15.7 & 8.8 & 26.5 \\
\hline Loads (MW / h) & 24.5 & 20.1 & 17.4 & 14.2 & 22 & 28.4 & 32.5 & 36.8 & 29.6 & 21.2 & 23.2 & 24.1 & 24.5 \\
\hline
\end{tabular}

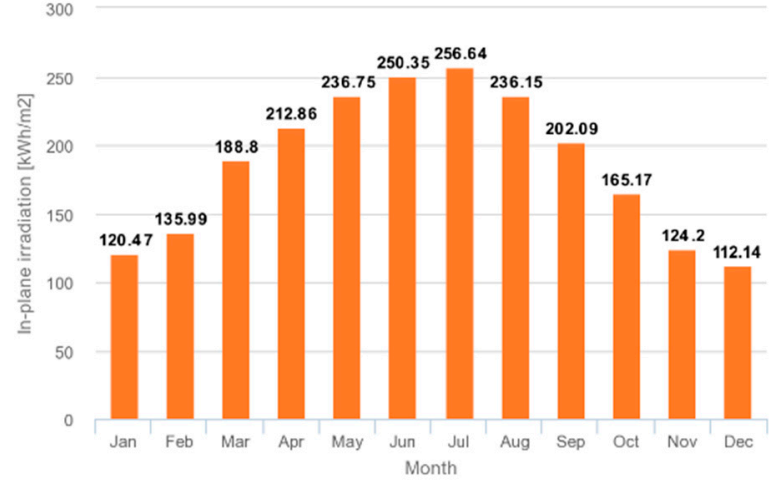

(a)

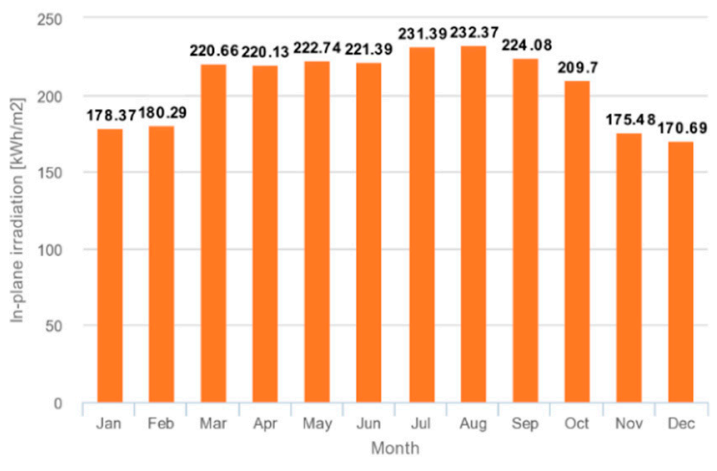

(b)

Figure 9. Monthly Solar Radiation on horizontal and $30^{\circ}$ tilt angle in $\mathrm{kWh} / \mathrm{m}^{2}$. (a): Horizontal plan. (b): On $30^{\circ}$ tilt angle.

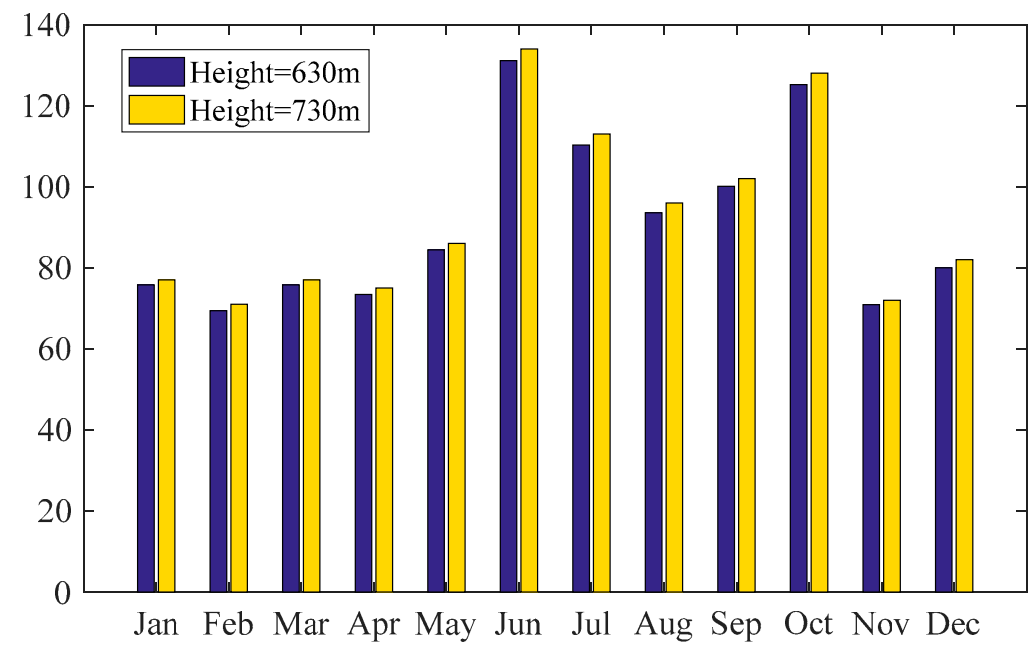

Figure 10. Monthly wind power $\left(\mathrm{kWh} / \mathrm{m}^{2}\right)$ on $630 \mathrm{~m}$ and $730 \mathrm{~m}$ heights. 


\subsection{Input Data}

An AE-Italia wind turbine (AMBIENTE ENERGIA SRL, Crispiano (TA), Italy) and a Panasonic VBHN325SA16 [1] are selected to be used as recommended in conducted previous studies near to this site $[1,12,47]$. The performance parameters of this wind turbine are shown in Table 2. Two types of PHES can be used, the first one is called single penstock which uses the same machine to work as a motor and generator, the other one is called double penstock system where each penstock is connected to a generator-turbine or motor-pump unit [62]. The single penstock system is simply cheaper in installation, meanwhile, it suffers from low efficiency and complex control system. The PHES system used in this study is a single penstock system which is having several units, where each unit consists of motor-pump and turbine-generator units with $1000 \mathrm{~kW}$ rated power [66].

Table 2. The specifications of different HRES components.

\begin{tabular}{|c|c|}
\hline Component & Specifications \\
\hline WT (AE-Italia) [47] & $\begin{array}{c}\operatorname{Pr}=60 \mathrm{~kW}, h_{w t}=30 \mathrm{~m}, U_{C}=2.5 \mathrm{~m} / \mathrm{s}, U_{R}=8 \mathrm{~m} / \mathrm{s}, \text { and } U_{F}=25 \mathrm{~m} / \mathrm{s}, T_{W T}=20 \text { years, cost of wind } \\
\text { turbines }=\$ 1500 / \mathrm{kW}[47], \text { OMC of wind turbines }=\$ 100 / \mathrm{kW} / \text { year }[46]\end{array}$ \\
\hline PV parameters [47] & $\begin{array}{l}\text { Cost of PV system }=\$ 200 / \mathrm{m}^{2}[46], \mathrm{OMC} \text { of } \mathrm{PV}=0.01 \times \text { cost of the PV system, salvage price of PV } \\
\text { array }=25 \% \text {, area of PV module }=1.67 \mathrm{~m}^{2}, \text { efficiency }=17 \% \text {, lifetime }=30 \text { years, } \beta t=0.005 \text { per }{ }^{\circ} \mathrm{C} \text {, } \\
T_{c r}=25^{\circ} \mathrm{C}\end{array}$ \\
\hline Inverter [47] & $\begin{array}{c}\text { Inverter cost }=\$ 410 / \mathrm{kW}, \text { inverter OMC }=\$ 10 / \mathrm{kW} / \text { year, salvage price of inverter }=\$ 50 / \mathrm{kW}, \\
\text { inverter life time }=10 \text { years, } \eta_{i n v}=0.95\end{array}$ \\
\hline Battery [47] & $\begin{array}{c}\text { Battery cost }=\$ 250 / \mathrm{kWh} \text {, battery } \mathrm{OMC}=\$ 0.02 / \mathrm{kWh} / \text { year, salvage value of battery }=20 \%) \cdot \operatorname{cost} \\
\text { of the battery, battery life }=10 \text { years, } \eta_{B C}=0.9, \eta_{B D}=0.95, \sigma=0.01 \%, \mathrm{DoD}=75 \%\end{array}$ \\
\hline Green Hydrogen & GHSS cost $=\$ 10,000 / \mathrm{kW}$, GHSS OMC $=\$ 500 / \mathrm{kW} /$ year, GHSS lifetime $=10$ years \\
\hline Pumped Storage & $\begin{array}{c}\text { Each unit has } 1000 \mathrm{~kW} \text { rated power, } \eta_{p m}=92 \%, \eta_{t u}=92 \%[67-69], \text { pump cost }=\$ 225 / \mathrm{kW} \text {, } \\
\text { turbine cost }=\$ 225 / \mathrm{kW} \text {, Civil construction cost of lakes and dam }=\$ 7.884 / \mathrm{kWh} \text { capacity, lifetime } \\
=50 \text { years }[69,70], \text { OMC of PHES per year }=1 \% \text { of total cost }\end{array}$ \\
\hline
\end{tabular}

\subsection{Optimization Algorithm Selection}

The proposed PSO optimization algorithm with a gradually reduced number of particles (GRP-PSO) has been compared with 10 other optimization techniques to show the superiority of the GRP-PSO optimization algorithm. This new proposed GRP-PSO optimization algorithm has been explained above where it will start with the same number of particles as other optimization algorithms and gradually reduce the number of particles by removing the worst particle in each iteration. The 10 optimization algorithms used for comparison with the new proposed PSO optimization algorithm are the conventional PSO [71], the PSO with a linear variation of inertia weight parameter [60], the grey wolf optimization GWO algorithm [72], the bat algorithm (BA) [1], artificial bee colony (ABC) [73], cuckoo search (CS) [74], bacterial foraging algorithm (BFA) [75], grasshopper optimization algorithm (GOA) [75], crow search algorithm (CSA) [76], and firefly algorithm (FFA) [77]. The value of $M$ weight value, $M$ of the objective function shown in Equation (29) is chosen by 1000 . The control parameters used with these optimization algorithms are shown in Table 3.

All the optimization algorithms started with 25 particles. The relation between the fitness function and convergence time for all optimization algorithms is shown in Figure 11.

The results obtained from this optimization study show the superiority of the GRPPSO compared to the other optimization algorithms understudy, as shown in Table 4, where it has the lowest convergence time $\left(t_{c}=3: 12 \mathrm{~h}\right.$ ), which is between $29 \%$ to $79 \%$ of the times consumed by other optimization algorithms. Moreover, the fitness value associated with the GRP-PSO is the lowest compared to the other optimization algorithms. Based on the outstanding results obtained from the GRP-PSO, it will be used with coming studies. 
Table 3. The control parameters of the benchmark optimization algorithms used in this study.

\begin{tabular}{ccc}
\hline No. & Technique & Control Parameters \\
\hline 1. & GRP-PSO & $\omega=0.9$ to $0.4, c_{1}=c_{2}=2.0$, particles started with 25 and gradually reduced by one in each iteration \\
$\omega=0.5, c_{1}=c_{2}=2.0$
\end{tabular}

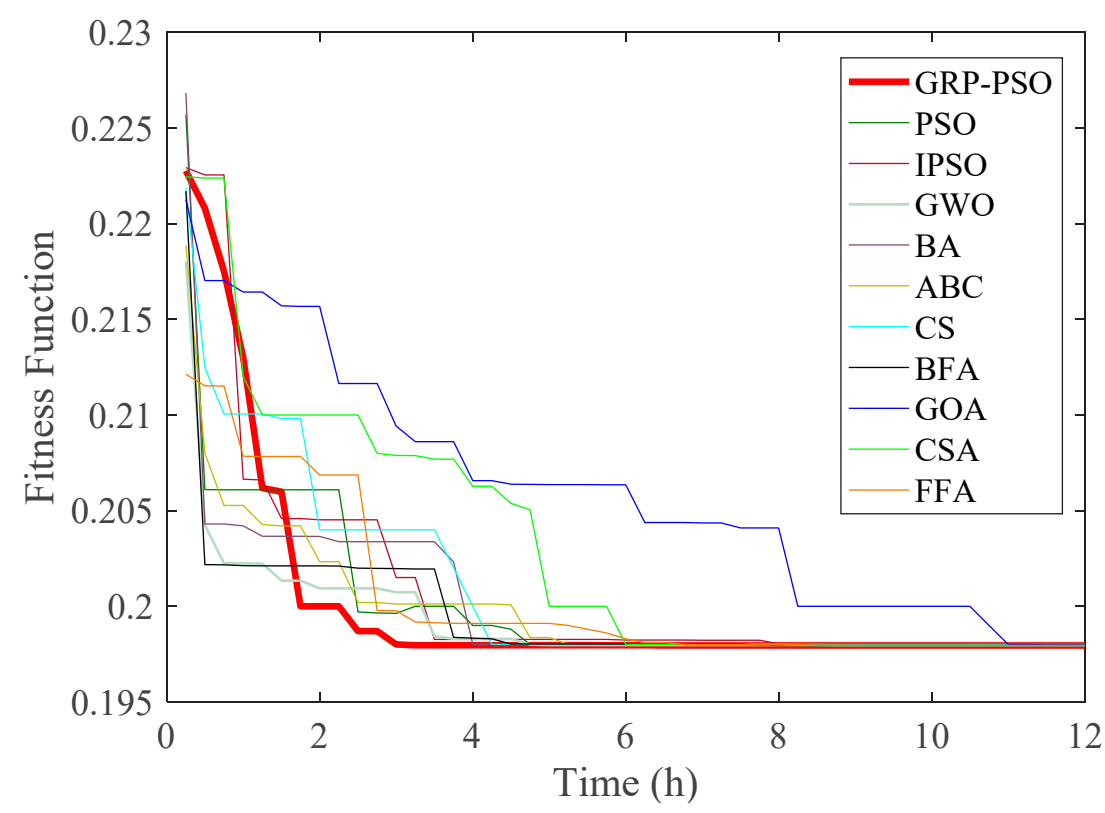

Figure 11. The fitness function against the convergence time for all optimization algorithms understudy.

Table 4. The convergence performance of different optimization algorithms under study.

\begin{tabular}{cccccc}
\hline Algorithm & $\boldsymbol{t c}$ & $\begin{array}{c}\boldsymbol{t}_{\boldsymbol{c}} \text { GRP-PSO \% of } \\
\text { Other Methods }\end{array}$ & $\begin{array}{c}\boldsymbol{L C E} \\
\mathbf{\$} / \mathbf{k W h}\end{array}$ & $\boldsymbol{E}_{\boldsymbol{U}}(\mathbf{M W h})$ & $\boldsymbol{F}$ \\
\hline GRP-PSO & $03: 12$ & - & 0.034325 & 65.554 & 0.198073 \\
PSO [70] & $04: 51$ & 66 & 0.035172 & 65.249 & 0.198158 \\
IPSO [59] & $04: 03$ & 79 & 0.034819 & 65.492 & 0.198413 \\
GWO [71] & $05: 18$ & 60 & 0.034725 & 65.594 & 0.198574 \\
BA [1] & $04: 13$ & 76 & 0.034615 & 65.656 & 0.198618 \\
\hline ABC [72] & $05: 27$ & 59 & 0.034852 & 65.560 & 0.198615 \\
CS [73] & $04: 21$ & 74 & 0.034987 & 65.550 & 0.198726 \\
BFA [74] & $04: 30$ & 71 & 0.034792 & 65.727 & 0.198972 \\
GOA [74] & $11: 07$ & 29 & 0.034845 & 65.594 & 0.198693 \\
CSA [75] & $06: 11$ & 52 & 0.035216 & 65.317 & 0.198374 \\
FFA [76] & $06: 53$ & 47 & 0.035178 & 65.411 & 0.198569 \\
\hline
\end{tabular}




\subsection{Energy Storage System Selection}

The study shown above recommended using the GRP-PSO as an optimization algorithm for sizing the HRES, and for this reason, it will be used with this study. In this study, three different ESS will be used to determine the most techno-economical one. The simulation results for three different strategies are shown in Table 5. It is clear from this figure that the PHES is contributing about $9.1 \%$ from the total cost of the HRES, meanwhile, the BSS and the GHSS are contributing $32.5 \%$, and $30.3 \%$, respectively. Moreover, the net cost of BSS and GHSS are 5.42 and 5.53 times the cost required for the PHES. The LCE for PHES is $65.8 \%$ and $58.9 \%$ compared to the system using the BSS and GHSS, respectively. The results obtained from this study show the superiority of using PHES as an ESS compared to the BSS and GHSS options. The next studies are performed for the use of PHES as an ESS due to its superiority.

Table 5. The cost comparison between the three different ESS used in this study.

\begin{tabular}{ccccc}
\hline ESS & ESS Cost & TPC & $\begin{array}{c}\text { LCE } \\
\mathbf{\$} / \mathbf{k W h}\end{array}$ & $\begin{array}{c}\text { ESS Cost/TPC } \\
\mathbf{( \% )}\end{array}$ \\
\hline PHES & $8,372,000$ & $91,773,592$ & 0.034325 & 9.1 \\
BSS & $45,358,473$ & $139,512,874$ & 0.052122 & 32.5 \\
GHSS & $46,242,507$ & $155,875,417$ & 0.058235 & 30.3 \\
\hline
\end{tabular}

\subsection{Voidance of Pollution Emissions}

Most of the loads around the Dumah AlJandal site are agriculture loads that are currently using diesel generators to generate electricity. The use of diesel fuel in generating electricity generates many greenhouse gases (GHG) such as carbon dioxide $\left(\mathrm{CO}_{2}\right)$, carbon monoxide $(\mathrm{CO})$, sulfur dioxide $\left(\mathrm{SO}_{2}\right)$, nitrogen oxides $\left(\mathrm{NO}_{\mathrm{x}}\right)$, and hydrocarbons $\left(\mathrm{CH}_{\mathrm{x}}\right)$. All these gases participate in air pollution which can cause acid rain, and cause many diseases for the residents which increases the health costs and contribute to many side effects on people and livestock. This avoidance of GHG will contribute to the pollution reduction targets in Saudi Arabia and if used in large numbers around the world, could reduce the effect of the global warming phenomenon. The avoidance of pollution due to the GHG emission when using diesel generators instead of using HRES with $100 \%$ green resources is shown in Table 6 [70].

Table 6. The avoidance of pollution due to the GHG emissions when using diesel generators instead of using HRES with 100\% green resources [70]. Reproduced from [70], Elsevier: 2014.

\begin{tabular}{cc}
\hline GHG & Emission (Ton/Year) \\
\hline $\mathrm{CO}_{2}$ & $2,493,320$ \\
$\mathrm{CO}$ & 616 \\
$\mathrm{SO}_{2}$ & 501 \\
$\mathrm{NO}_{\mathrm{x}}$ & 5493 \\
$\mathrm{CH}_{\mathrm{x}}$ & 70 \\
\hline
\end{tabular}

\subsection{Effect of Load Elasticity}

Demand response is one of the smart grid concepts in which the system uses dynamic tariffs to convince customers to adapt their loads based on the stability system situation. In this strategy, based on three different factors, the system will change the tariff which is the volume of water in the upper lake, power difference, and the forecast factor of weather data and loads. The change in tariff has been discussed in detail above, where, in this section, the effect of power elasticity demand (PED) on the size of components, size of ESS, cost of the system, and cost of energy is shown in Figure 12. For sure, the participation of customers in the stability of the system will reduce the system size and the cost of energy based on their response (PED). Figure 12 and Table 7 show the change in system size components with different values of $P E D, 0$ (flat tariff), $-1,-2$, respectively. It is clear 
from Table 7 that, the TPC and the LCE of the HRES are reduced to $71.5 \%$ when used the DRS with -1 elasticity compared to the flat rate tariff. These outstanding results prove the superiority of using the DRS in the sizing and operation of the HRES.

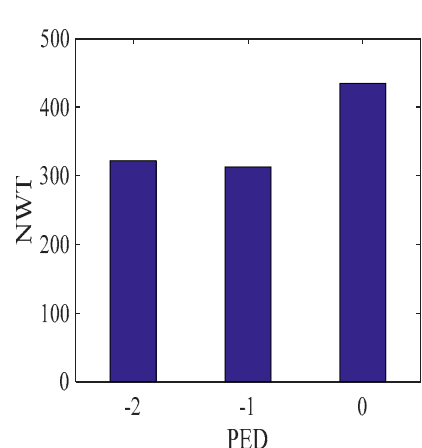

(a)

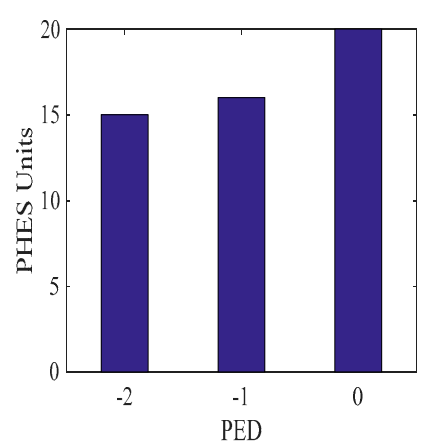

(d)

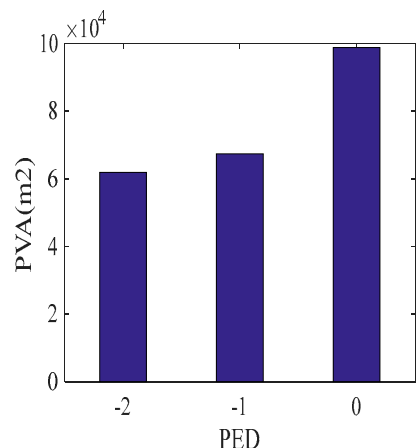

(b)

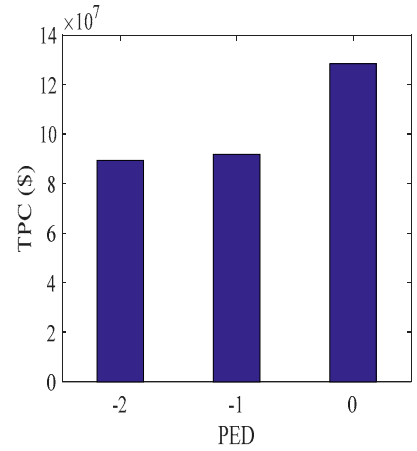

(e)

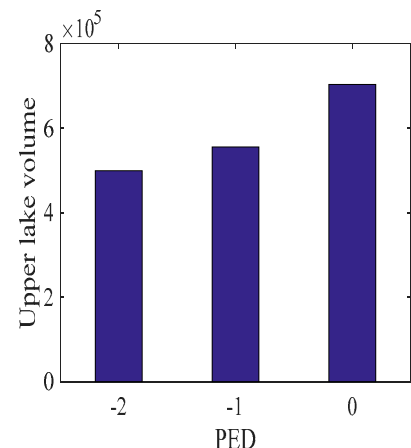

(c)

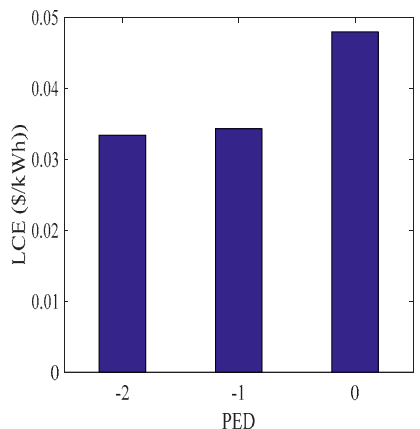

$(\mathbf{f})$

Figure 12. The variation of different performance parameters with $P E D$ values. (a): NWT. (b): PVA. (c): Upper lake volume.(d): PHES Units. (e): TPC. (f): LCE.

Table 7. The change in system size components with different values of $P E D, 0$ (flat tariff), $-1,-2$, respectively.

\begin{tabular}{cccc}
\hline Item & PED $=\mathbf{0}$ & PED $=-\mathbf{1}$ & PED = - \\
\hline$N W T$ & 435 & 313 & 322 \\
$P V A\left(\mathrm{~m}^{2}\right)$ & 98,749 & 67,318 & 61,875 \\
$V_{U}^{\max }\left(\mathrm{m}^{3}\right)$ & 702,825 & 554,862 & 498,981 \\
$P H E S$ & 20 & 16 & 15 \\
$T P C(\$)$ & $128,456,850$ & $91,877,860$ & $89,478,260$ \\
$L C E(\$ / \mathrm{kWh})$ & 0.047991351 & 0.034325477 & 0.033428989 \\
\hline
\end{tabular}

\subsection{Sensitivity Analysis}

The sensitivity analysis is introduced in this paper to predict the variation of different inputs on the cost of energy of the proposed HRES. All the sensitivity analysis studies introduced in this section are performed with GRP-PSO, PHES, and PED $=-1$.

The first sensitivity study introduced in this paper is to predict the change in $L C E$ with $\pm 20 \%$ change in wind speed. For sure the increase in wind speed will reduce the $L C E$ and will increase the generating energy from the available components or the size of HRES may be reduced. The changes in LCE with $\pm 20 \%$ change in wind speed are shown in Figure 13 . The maximum increase due to a $-20 \%$ reduction in wind speed is $1.3 \%$ from the TPC and LCE of the HRES. Also, the maximum reduction in the TPC and LCE of the HRES due to an increase in wind speed by $20 \%$ is $-1.25 \%$. These results show that is not very sensitive to a small change in wind speed where a change in wind speed by $\pm 20 \%$ changed the TPC and $L C E$ by about $\pm 1.3 \%$ with respect to the actual data of the wind speed. 


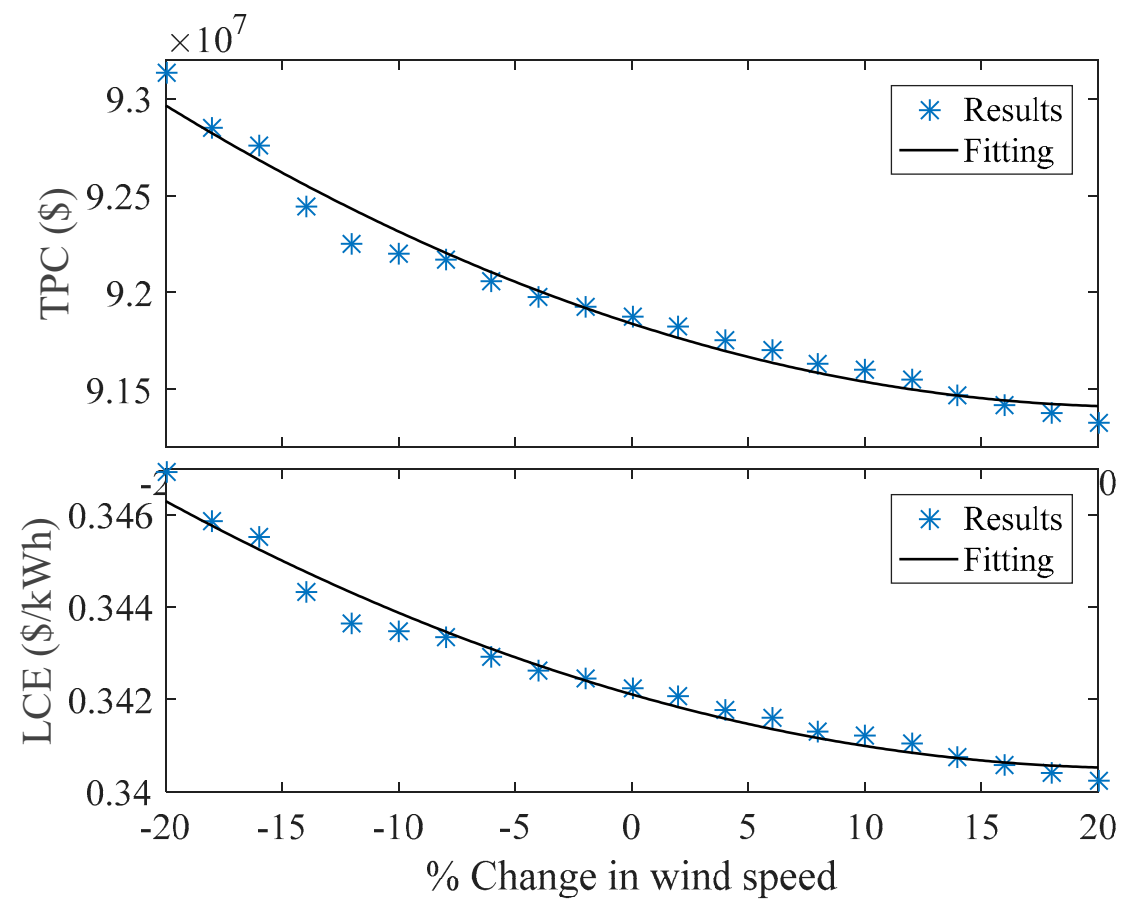

Figure 13. The variations of TPC and LCE along with $\pm 20 \%$ change in wind speed.

The second sensitivity study is performed for $\pm 20 \%$ change in solar radiation to predict the change in $L C E$ with $\pm 20 \%$ change in solar irradiance. For sure, the increase in solar irradiances will reduce the LCE and will increase the generating energy from the available components or the size of HRES may be reduced and vice versa. The change in $L C E$ with $\pm 20 \%$ change in solar irradiance is shown in Figure 14 . The maximum increase due to a $-20 \%$ reduction in solar irradiance is $1.22 \%$ from the TPC and LCE of the HRES. Also, the maximum reduction in the TPC and LCE of the HRES due to an increase in solar irradiance by $20 \%$ is $-0.8 \%$. These results show that the HRES is not very sensitive to a small change in solar irradiance where a change in solar irradiance by $\pm 20 \%$ changed the TPC and LCE by about $+1.22 \%$ to $-0.8 \%$ with respect to the actual data of the solar irradiance.

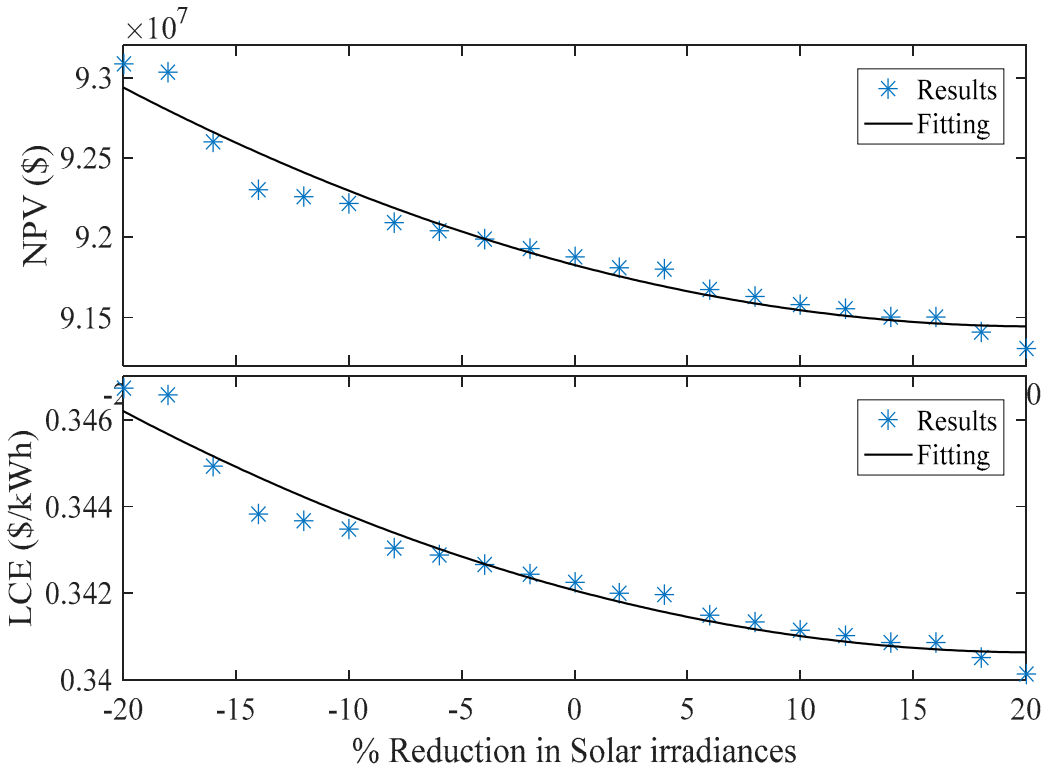

Figure 14. The variations of TPC and LCE along with $\pm 20 \%$ change in solar irradiance. 


\section{Conclusions}

Several challenges facing the installation of hybrid renewable energy systems (HRES) such as the selection of the most feasible energy storage system (ESS) type, the use of smart grid concepts like demand response to improve the performance of the HRES and reduce the cost of energy and the long convergence time to design the optimal sizes of the HRES components. All these challenges have been avoided in this proposed study as shown in the following points:

- The challenge of selecting the most suitable ESS is studied in this paper, where pumped hydro energy storage (PHES) is selected due to the suitability of the selected location to build this technology. The presence of a $100 \mathrm{~m}$ difference between the upper and lower lake makes the PHRS a very attractive option. The PHES is compared with a battery storage system (BSS) and a green hydrogen storage system (GHSS). The HRES with the PHES as an ESS is giving $\$ 0.034325 / \mathrm{kWh}$ Levelized cost of energy compared to $\$ 0.052122 / \mathrm{kWh}$ and $\$ 0.058235 / \mathrm{kWh}$ for the HRES uses BSS and GHSS ESS systems, respectively. The cost of the PHES contributes $9.1 \%$ of the total HRES cost compared to $32.5 \%$ and $30.3 \%$ for the HRES using BSS and GHSS, respectively. The cost of installing the BSS and GHSS are 5.42 and 5.53 times the cost associated with PHES used for the same purpose. These outstanding results proved the superiority of using PHES as an ESS compared to the BSS and GHSS technologies.

- The use of traditional swarm optimization techniques in the sizing of the HRES is spending a long time in the optimization algorithm which imposes a challenge for the sizing of the HRES. In this study, a modified optimization strategy called the gradually reduced particles of particle swarm optimization (GRP-PSO) algorithm is introduced in this paper. The GRP-PSO removes the worst particles in each iteration of the optimization steps. The GRP-PSO reduced the convergence time to $29 \%$ to $79 \%$ compared to the convergence time of the 10 optimization algorithms selected in this study. These outstanding results proved the superiority of the GRP-PSO in the sizing of the HRES.

- The use of the proposed HRES with 100\% green energy avoids 2.5 million tons per year of greenhouse gases which substantially improves the quality of life around the selected sites and participates in reducing the global warming phenomena if a similar system is installed in Saudi Arabia and other sites in the world.

- The use of demand response strategy as a concept of the smart grid is improving the HRES stability and substantially reduces the TPC and LCE. The model of the DRS used in this paper is implemented using a fuzzy logic controller with a novel forecast factor used in the simulation. The TPC and the LCE of the HRES are reduced to $71.5 \%$ when used the DRS with -1 elasticity compared to the flat rate tariff. These outstanding results prove the superiority of using the DRS in the sizing and operation of the HRES.

Two sensitivity analysis studies are introduced in this paper to predict the variation of the LCE on any change in wind speed or solar irradiances data used in the available data. With $\pm 20 \%$ change in wind speed or solar irradiances, the variation of the TPC and the LCE never go beyond $\pm 1.3 \%$ change which proves the proposed system is having low sensitivity with a substantial change in wind speed or solar irradiances.

Author Contributions: Conceptualization, M.A.A. and A.M.E.; methodology, M.A.A. and A.M.E.; software, A.M.E.; validation, M.A.A. and A.M.E.; formal analysis, M.A.A. and A.M.E.; investigation, M.A.A. and A.M.E.; resources, M.A.A. and A.M.E.; data curation, M.A.A. and A.M.E.; writingoriginal draft preparation, M.A.A. and A.M.E.; writing-review and editing, M.A.A. and A.M.E.; visualization, M.A.A. and A.M.E.; supervision, M.A.A. and A.M.E.; project administration, M.A.A. and A.M.E.; funding acquisition, M.A.A. All authors have read and agreed to the published version of the manuscript.

Funding: The Deanship of Scientific Research at King Saud University for funding this work through research group No (RG- 1441-422). 
Institutional Review Board Statement: Not applicable.

Informed Consent Statement: Not applicable.

Data Availability Statement: Not applicable.

Acknowledgments: The authors extend their appreciation to the Deanship of Scientific Research at King Saud University for funding this work through research group No (RG- 1441-422).

Conflicts of Interest: The authors declare no conflict of interest.

\section{References}

1. Eltamaly, A.M.; Alotaibi, M.A.; Alolah, A.I.; Ahmed, M.A. A Novel Demand Response Strategy for Sizing of Hybrid Energy System With Smart Grid Concepts. IEEE Access 2021, 9, 20277-20294. [CrossRef]

2. Zhang, Z.; Wang, J.; Wang, X. An improved charging/discharging strategy of lithium batteries considering depreciation cost in day-ahead microgrid scheduling. Energy Convers. Manag. 2015, 105, 675-684. [CrossRef]

3. IEA. The Role of Critical Minerals in Clean Energy Transitions; IEA: Paris, France, 2021. Available online: https://www.iea.org/ reports / the-role-of-critical-minerals-in-clean-energy-transitions (accessed on 1 June 2021).

4. Ishaq, H.; Dincer, I. Comparative assessment of renewable energy-based hydrogen production methods. Renew. Sustain. Energy Rev. 2021, 135, 110192. [CrossRef]

5. $\quad$ Donalek, P.; Trouille, B.; Hartel, P.; King, K.; Bhattarai, M.; Krohn, R.; Gilbert, K.; Lee, H.; Haapala, J. Technical Analysis of Pumped Storage and Integration with Wind Power in the Pacific Northwest; MWH Americas, Inc.: Broomfield, CO, USA, 2009.

6. Javed, M.S.; Zhong, D.; Ma, T.; Song, A.; Ahmed, S. Hybrid pumped hydro and battery storage for renewable energy based power supply system. Appl. Energy 2020, 257, 114026. [CrossRef]

7. Bhattacharjee, S.; Nayak, P.K. PV-pumped energy storage option for convalescing performance of hydroelectric station under declining precipitation trend. Renew. Energy 2019, 135, 288-302. [CrossRef]

8. Xu, X.; Hu, W.; Huang, Q.; Chen, Z. Optimal Operation of Photovoltaic-Pump Hydro Storage Hybrid System. In Proceedings of the 2018 IEEE PES Asia-Pacific Power and Energy Engineering Conference (APPEEC), Kota Kinabalu, Malaysia, 7-10 October 2018; pp. 194-199.

9. Koko, S.P.; Kusakana, K.; Vermaak, H.J. Optimal power dispatch of a grid-interactive micro-hydrokinetic-pumped hydro storage system. J. Energy Storage 2018, 17, 63-72. [CrossRef]

10. Sun, K.; Li, K.-J.; Pan, J.; Liu, Y.; Liu, Y. An optimal combined operation scheme for pumped storage and hybrid wind-photovoltaic complementary power generation system. Appl. Energy 2019, 242, 1155-1163. [CrossRef]

11. Duchaud, J.-L.; Notton, G.; Darras, C.; Voyant, C. Multi-Objective Particle Swarm optimal sizing of a renewable hybrid power plant with storage. Renew. Energy 2019, 131, 1156-1167. [CrossRef]

12. Eltamaly, A.M.; Alotaibi, M.A. Novel Fuzzy-Swarm Optimization for Sizing of Hybrid Energy Systems Applying Smart Grid Concepts. IEEE Access 2021, 9, 93629-93650. [CrossRef]

13. Mohamed, M.A.; Eltamaly, A.M.; Alolah, A. Swarm intelligence-based optimization of grid-dependent hybrid renewable energy systems. Renew. Sustain. Energy Rev. 2017, 77, 515-524. [CrossRef]

14. Sandhu, K.; Mahesh, A. Optimal sizing of PV/wind/battery Hybrid Renewable Energy System Considering Demand Side Management. Int. J. Electr. Eng. Inform. 2018, 10, 79-93. [CrossRef]

15. Singh, S.; Kaushik, S.C. Optimal sizing of grid integrated hybrid PV-biomass energy system using artificial bee colony algorithm. IET Renew. Power Gener. 2016, 10, 642-650. [CrossRef]

16. Ishaq, H.; Siddiqui, O.; Chehade, G.; Dincer, I. A solar and wind driven energy system for hydrogen and urea production with $\mathrm{CO}_{2}$ capturing. Int. J. Hydrogen. Energy 2021, 46, 4749-4760. [CrossRef]

17. Abushnaf, J.; Rassau, A. Impact of energy management system on the sizing of a grid-connected PV/Battery system. Electr. J. 2018, 31, 58e66. [CrossRef]

18. Eltamaly, A.M.; Addoweesh, K.E.; Bawah, U.; Mohamed, M.A. New software for hybrid renewable energy as-sessment for ten locations in Saudi Arabia. J. Renew. Sustain. Energy 2013, 5, 033126. [CrossRef]

19. Eltamaly, A.M.; Mohamed, M.A. A novel software for design and optimization of hybrid power systems. J. Braz. Soc. Mech. Sci. Eng. 2016, 38, 1299-1315. [CrossRef]

20. Zhang, Y.; Lundblad, A.; Campana, P.E.; Benavente, F.; Yan, J. Battery sizing and rule-based operation of grid-connected photovoltaic-battery system: A case study in Sweden. Energy Convers. Manag. 2017, 133, 249-263. [CrossRef]

21. El-Tamaly, H.H.; El-Tamaly, A.M.; El-Baset Mohammed, A.A. Design and control strategy of utility interfaced PV/WTG hybrid system. In Proceedings of the Ninth International Middle East Power System Conference-MEPCON, Shpein Alkum, Egypt, 18-20 December 2003; pp. 16-18.

22. Abdelshafy, A.M.; Hassan, H.; Jurasz, J. Optimal design of a gridconnected desalination plant powered by renewable energy resources using a hybrid PSOeGWO approach. Energy Convers Manag. 2018, 173, 331e47. [CrossRef]

23. Zebarjadi, M.; Askarzadeh, A. Optimization of a reliable grid-connected PV-based power plant with/without energy storage system by a heuristic approach. Sol. Energy 2016, 125, 12-21. [CrossRef] 
24. Chen, J.; Zhang, W.; Li, J.; Zhang, W.; Liu, Y.; Zhao, B.; Zhang, Y. Optimal Sizing for Grid-Tied Microgrids With Consideration of Joint Optimization of Planning and Operation. IEEE Trans. Sustain. Energy 2018, 9, 237-248. [CrossRef]

25. Zhang, Y.; Campana, P.E.; Lundblad, A.; Yan, J. Comparative study of hydrogen storage and battery storage in grid connected photovoltaic system: Storage sizing and rule-based operation. Appl. Energy 2017, 201, 397-411. [CrossRef]

26. Eltamaly, A.M.; Mohamed, M.A.; Alolah, A.I. A novel smart grid theory for optimal sizing of hybrid renewable energy systems. Sol. Energy 2016, 124, 26-38. [CrossRef]

27. Eltamaly, A. A Novel Strategy for Optimal PSO Control Parameters Determination for PV Energy Systems. Sustainability 2021, 13, 1008. [CrossRef]

28. Eltamaly, A.M.; Al-Saud, M.S.; Abokhalil, A.G. A Novel Bat Algorithm Strategy for Maximum Power Point Tracker of Photovoltaic Energy Systems Under Dynamic Partial Shading. IEEE Access 2020, 8, 10048-10060. [CrossRef]

29. Eltamaly, A.M.; Al-Saud, M.; Abokhalil, A.G.; Farh, H.M.H. Simulation and experimental validation of fast adaptive particle swarm optimization strategy for photovoltaic global peak tracker under dynamic partial shading. Renew. Sustain. Energy Rev. 2020, 124, 109719. [CrossRef]

30. Eltamaly, A.M.; Mohamed, M.A.; Al-Saud, M.S.; Alolah, A.I. Load management as a smart grid concept for sizing and designing of hybrid renewable energy systems. Eng. Optim. 2016, 49, 1813-1828. [CrossRef]

31. Alzara, M. Virtual Rebuilding and Documentation of the Historical Old Market of Domat Al-Jandal City. Civ. Eng. Arch. 2021, 9, 512-522. [CrossRef]

32. Al-Jandal, D. Exploring the Kingdom's Largest Natural Lake. Available online: https://www.wafyapp.com/en/article/ exploring-the-kingdoms-largest-natural-lake-dawmat-al-jandal (accessed on 27 September 2021).

33. Topographic Maps. Available online: https:/ / en-au.topographic-map.com (accessed on 27 September 2021).

34. Mohamed, M.A.; Eltamaly, A.M.; Alolah, A.I.; Hatata, A. A novel framework-based cuckoo search algorithm for sizing and optimization of grid-independent hybrid renewable energy systems. Int. J. Green Energy 2019, 16, 86-100. [CrossRef]

35. Eltamaly, A.M.; Al-Shamma'A, A.A. Optimal configuration for isolated hybrid renewable energy systems. J. Renew. Sustain. Energy 2016, 8, 045502. [CrossRef]

36. Eltamaly, A.M. Pairing between Sites and Wind Turbines for Saudi Arabia Sites. Arab. J. Sci. Eng. 2014, 39, 6225-6233. [CrossRef]

37. Eltamaly, A. An Improved Cuckoo Search Algorithm for Maximum Power Point Tracking of Photovoltaic Systems under Partial Shading Conditions. Energies 2021, 14, 953. [CrossRef]

38. Eltamaly, A.M. Performance of MPPT Techniques of Photovoltaic Systems Under Normal and Partial Shading Conditions. In Advances in Renewable Energies and Power Technologies; Elsevier: Amsterdam, The Netherlands, 2018; pp. 115-161.

39. Eltamaly, A.M. A novel musical chairs algorithm applied for MPPT of PV systems. Renew. Sustain. Energy Rev. 2021, 146, 111135. [CrossRef]

40. Skoplaki, E.; Boudouvis, A.; Palyvos, J. A simple correlation for the operating temperature of photovoltaic modules of arbitrary mounting. Sol. Energy Mater. Sol. Cells 2008, 92, 1393-1402. [CrossRef]

41. Kusakana, K. Feasibility analysis of river off-grid hydrokinetic systems with pumped hydro storage in rural applications. Energy Convers. Manag. 2015, 96, 352-362. [CrossRef]

42. Dufo-López, R.; Bernal-Agustín, J. Multi-objective design of PV-wind-diesel-hydrogen-battery systems. Renew. Energy 2008, 33, 2559-2572. [CrossRef]

43. Awan, A.B.; Zubair, M.; Sidhu, G.A.S.; Bhatti, A.R.; Abo-Khalil, A.G. Performance analysis of various hybrid renewable energy systems using battery, hydrogen, and pumped hydro-based storage units. Int. J. Energy Res. 2019, 43, 6296-6321. [CrossRef]

44. Luo, Y.; Wu, Y.; Li, B.; Qu, J.; Feng, S.; Chu, P.K. Optimization and cutting-edge design of fuel-cell hybrid electric vehicles. Int. J. Energy Res. 2021, 45, 18392-18423. [CrossRef]

45. Castañeda, M.; Cano, A.; Jurado, F.; Sánchez-Sáinz, H.; Fernández-Ramirez, L.M. Sizing optimization, dynamic modeling and energy management strategies of a stand-alone PV/hydrogen/battery-based hybrid system. Int. J. Hydrogen Energy 2013, 38, 3830-3845. [CrossRef]

46. Maleki, A.; Pourfayaz, F.; Ahmadi, M.H. Design of a cost-effective wind/photovoltaic/hydrogen energy system for supplying a desalination unit by a heuristic approach. Sol. Energy 2016, 139, 666-675. [CrossRef]

47. Eltamaly, A.M.; Ali, E.; Bumazza, M.; Mulyono, S.; Yasin, M. Optimal Design of Hybrid Renewable Energy System for a Reverse Osmosis Desalination System in Arar, Saudi Arabia. Arab. J. Sci. Eng. 2021, 46, 9879-9897. [CrossRef]

48. Cheng, Y.-S.; Hesse, H.; Truong, N.; Jossen, A.; Liu, Y.-H. Charging Strategy for a Residential Battery Storage System using Fuzzy Logic Controller. In Proceedings of the NEIS Conference, Hamburg, Germany, 15-16 September 2016; pp. 182-189.

49. Abu-Rayash, A.; Dincer, I. Development and analysis of an integrated solar energy system for smart cities. Sustain. Energy Technol. Assess. 2021, 46, 101170. [CrossRef]

50. Yang, H.; Zhou, W.; Lu, L.; Fang, Z. Optimal sizing method for stand-alone hybrid solar-wind system with LPSP technology by using genetic algorithm. Sol. Energy 2008, 82, 354-367. [CrossRef]

51. Guasch, D.; Silvestre, S. Dynamic battery model for photovoltaic applications. Prog. Photovolt. Res. Appl. 2003, 11, 193-206. [CrossRef]

52. Eltamaly, A.M. February. Modeling of fuzzy logic controller for photovoltaic maximum power point tracker. In Proceedings of the Solar Future 2010 Conference, Istanbul, Turkey, 11-12 February 2010. 
53. Clerc, M.; Kennedy, J. The particle swarm-Explosion, stability, and convergence in a multidimensional complex space. IEEE Trans. Evol. Comput. 2002, 6, 58-73. [CrossRef]

54. Clerc, M. The swarm and the queen: Towards a deterministic and adaptive particle swarm optimization. In Proceedings of the 1999 Congress on Evolutionary Computation-CEC99 (Cat. No. 99TH8406), Washington, DC, USA, 6-9 July 1999; pp. $1951-1957$.

55. Jiang, M.; Luo, Y.; Yang, S. Particle swarm optimization-stochastic trajectory analysis and parameter selection. In Swarm Intelligence, Focus on Ant and Particle Swarm Optimization, 11th ed.; Chan, F., Kumar, Tiwari, M., Eds.; IntechOpen: London, UK, 2007.

56. Eltamaly, A.M.; Al-Saud, M.S. Nested multi-objective PSO for optimal allocation and sizing of renewable energy distributed generation. J. Renew. Sustain. Energy 2018, 10, 035302. [CrossRef]

57. Clerc, M. Stagnation analysis in particle swarm optimisation or what happens when nothing happens. HAL 2006, 1, 1-10.

58. Liu, Q. Order-2 stability analysis of particle swarm optimization. Evol. Comput. 2015, 23, 187-216. [CrossRef] [PubMed]

59. Harrison, K.R.; Engelbrecht, A.P.; Ombuki-Berman, B.M. An adaptive particle swarm optimization algorithm based on optimal parameter regions. In Proceedings of the 2017 IEEE Symposium Series on Computational Intelligence (SSCI), Honolulu, HI, USA, 27 November-1 December 2017; pp. 1-8.

60. Shi, Y.; Eberhart, R.C. Empirical study of particle swarm optimization. In Proceedings of the 1999 Congress on Evolutionary Computation-CEC99 (Cat. No. 99TH8406), Washington, DC, USA, 6-9 July 1999; pp. 1945-1950. [CrossRef]

61. Hu, K.; Cao, S.; Li, W.; Zhu, F. An Improved Particle Swarm Optimization Algorithm Suitable for Photovoltaic Power Tracking Under Partial Shading Conditions. IEEE Access 2019, 7, 143217-143232. [CrossRef]

62. Hakimi, S.M.; Moghaddas-Tafreshi, S.M. Optimal sizing of a stand-alone hybrid power system via particle swarm optimization for Kahnouj area in south-east of Iran. Renew. Energy 2009, 34, 1855-1862. [CrossRef]

63. Eltamaly, A.M.; Mohamed, M.A. Optimal Sizing and Designing of Hybrid Renewable Energy Systems in Smart Grid Applications. In Advances in Renewable Energies and Power Technologies; Elsevier: Amsterdam, The Netherlands, 2018; pp. 231-313.

64. Carpentiero, V.; Langella, R.; Manco, T.; Markovian, T.A.A. A markovian Approach to Size a Hybrid Wind-Diesel Stand Alone System. In Proceedings of the Tenth International Conference on Probabilistic Methods Applied to Power Systems-PMAPS'08, Rincon, PR, USA, 25-29 May 2008.

65. Belmilia, H.; Almia, M.F.; Bendiba, B.; Boloumaa, S. A computer program development for sizing stand-alone Photovoltaic-Wind hybrid systems. Int Conf. Energy Procedia Elsevier 2013, 36, 546-557. [CrossRef]

66. Rehman, S.; Al-Hadhrami, L.M.; Alam, M.M. Pumped hydro energy storage system: A technological review. Renew. Sustain. Energy Rev. 2015, 44, 586-598. [CrossRef]

67. Photovoltaic Geographical Information System. Available online: https:/ / re.jrc.ec.europa.eu/pvg_tools/en/ (accessed on 1 June 2021).

68. Ramli, M.A.; Twaha, S.; Al-Hamouz, Z. Analyzing the potential and progress of distributed generation applications in Saudi Arabia: The case of solar and wind resources. Renew. Sustain. Energy Rev. 2017, 70, 287-297. [CrossRef]

69. Connolly, D.; Lund, H.; Finn, P.; Mathiesen, B.; Leahy, M. Practical operation strategies for pumped hydroelectric energy storage (PHES) utilising electricity price arbitrage. Energy Policy 2011, 39, 4189-4196. [CrossRef]

70. Ma, T.; Yang, H.; Lu, L.; Peng, J. Technical feasibility study on a standalone hybrid solar-wind system with pumped hydro storage for a remote island in Hong Kong. Renew. Energy 2014, 69, 7-15. [CrossRef]

71. Etamaly, A.M.; Mohamed, M.A.; Alolah, A.I. A smart technique for optimization and simulation of hybrid photovoltaic/wind/diesel/battery energy systems. In Proceedings of the 2015 IEEE International Conference on Smart Energy Grid Engineering (SEGE), Oshawa, ONT, Canada, 17-19 August 2015.

72. El-Bidairi, K.S.; Nguyen, H.D.; Jayasinghe, S.; Mahmoud, T.S.; Penesis, I. A hybrid energy management and battery size optimization for standalone microgrids: A case study for Flinders Island, Australia. Energy Convers. Manag. 2018, 175, 192-212. [CrossRef]

73. Singh, S.; Singh, M.; Kaushik, S.C. Feasibility study of an islanded microgrid in rural area consisting of PV, wind, biomass and battery energy storage system. Energy Convers. Manag. 2016, 128, 178-190. [CrossRef]

74. Sanajaoba, S.; Fernandez, E. Maiden application of Cuckoo Search algorithm for optimal sizing of a remote hybrid renewable energy System. Renew. Energy 2016, 96, 1-10. [CrossRef]

75. Ullah, I.; Khitab, Z.; Khan, M.N.; Hussain, S. An Efficient Energy Management in Office Using Bio-Inspired Energy Optimization Algorithms. Processes 2019, 7, 142. [CrossRef]

76. Makhdoomi, S.; Askarzadeh, A. Optimizing operation of a photovoltaic/diesel generator hybrid energy system with pumped hydro storage by a modified crow search algorithm. J. Energy Storage 2020, 27, 101040. [CrossRef]

77. Sanajaoba, S. Optimal sizing of off-grid hybrid energy system based on minimum cost of energy and reliability criteria using firefly algorithm. Sol. Energy 2019, 188, 655-666. [CrossRef] 